\title{
Improperly Divorced from Its Roots: The Rationales of the Collateral Source Rule and Their Implications for Medicare and Medicaid Write-Offs
}

\section{INTRODUCTION}

Dubbed an "oddit[y] of American accident law,"1 the collateral source rule travels the path to extinction. ${ }^{2}$ Currently, only twelve states retain the rule's immaculate common law form. ${ }^{3}$ Reacting to a perceived medical malpractice crisis, ${ }^{4}$ twenty states have modified the rule, ${ }^{5}$ and, in

Guillermo Gabriel Zorogastua. J.D. candidate 2007, The University of Kansas School of Law; B.A., B.S. 2004, Wichita State University. Thanks to Doug Bell, M.A. Kautsch, Sandra McKenzie, Dennis D. Prater, David G. Seely, and Lyndon W. Vix for their helpful comments and suggestions. I dedicate this piece to my family and to Phil Mellor, an attorney who showed me the joy of the practice and study of law. Additionally, I owe much of this piece to Donald C. Davisthank you for all the time you invested in me.

1. John G. Fleming, The Collateral Source Rule and Loss Allocation in Tort Law, 54 CAL. L. REV. 1478, 1478 (1966).

2. See James L. Branton, The Collateral Source Rule, 18 ST. MARY's L.J. 883, 887-88 n.23 (1987) (compiling statutes that abolished the collateral source rule in whole or in part); Christopher J. Eaton, Comment, The Kansas Legislature's Attempt to Abrogate the Collateral Source Rule: Three Strikes and They're Out?, 42 U. KAN. L. REV. 913, 916-20 (1994) (surveying the Kansas legislature's three unsuccessful attempts to modify the Kansas collateral source rule).

3. As of February 2006, only the common law collateral source rules in Arkansas, Louisiana, Mississippi, New Mexico, North Carolina, South Carolina, Texas, Vermont, Virginia, West Virginia, and Wyoming remain intact. Melinda Young, Note, Victim's Rights Versus Special Interest: A Difficult Choice for the Kansas Legislature in Its Fight to Abrogate the Collateral Source Rule, 45 WASHBURN L.J. 135, 137 n.24 (2005); see also CTR. FOR JUSTICE \& DEMOCRACY, THE MEDICAL Profession-More Protection for Negligence than ANy Profession in the Country (2005), http://www.centerjd.org/free/medmallist.htm (compiling changes in tort reform in the fifty states). Hawaii's unique collateral source rule allows third parties to file liens against the plaintiff's award and does not permit evidence of collateral source benefits to reduce the plaintiff's damages. Young, supra, at 137 n.24.

4. See infra note 117 (citing articles detailing the perceived medical malpractice crisis).

5. Several states have abrogated the rule only in the medical malpractice context. For example, California allows defendants to introduce evidence of collateral source payments in actions based on the professional negligence of a medical service provider. CAL. CIV. CODE $\S 3333.1$ (West 1997). Similarly, South Dakota permits the admissibility of collateral source payments in actions against medical service providers for "special damages" if the benefit was paid or is payable by insurance, the benefit is not subject to subrogation, and the benefit is not purchased privately or paid for or payable by government programs. S.D. CoDIFIED LAWS $§ 21-3-12$ (2004). The following states possess similar statutes: Arizona (ARIZ. ReV. STAT. ANN. § 12-565 (2003)), Delaware (DeL. Code AnN. tit. 18, § 6862 (1999)), Maine (Me. Rev. Stat. AnN. tit. 24, § 2906(2) (2000)), 
even more ambitious attempts at tort reform, fourteen states have simply abrogated the rule. ${ }^{6}$ Courts in four states, including Kansas, have found these legislative measures unconstitutional. ${ }^{7}$

Comprehending the conflict over the Kansas collateral source rule requires understanding the rule itself. The rule prohibits a defendant from introducing evidence of benefits or payments made by a third party unrelated to the defendant. ${ }^{8}$ Although somewhat counterintuitive, the doctrine effectively allows courts to award plaintiffs the reasonable value of their economic damages, ${ }^{9}$ even if a third party paid on the plaintiff's

Maryland (MD. Code ANN., CTS. \& Jud. Proc. § 3-2A-06(f) (LexisNexis 2002)), Massachusetts (MASS. GEN. LAwS ANN. ch. 231, § 60G(a) (West 2000)), Nevada (NEV. ReV. Stat. § 42.021 (2005)), Oklahoma (OKLA. STAT. ANN. tit. 63, § 1-1708.1D (West 2004)), Rhode Island (R.I. GEN. LAWS § 9-19-34.1 (1997)), Tennessee (TENN. CODE ANN. § 29-26-119 (2000)), Utah (UTAH CODE ANN. § 78-14-4.5 (2002)), Washington (WASH. REV. CODE ANN. § 7.70 .080 (West 1992)), and Wisconsin (WIS. STAT. ANN. § 893.55(7) (West 2006)). Other states have abrogated the rule in particular situations. See, e.g., 735 ILL. COMP. STAT. ANN. 5/2-1205.1 (West 2003) (providing for offsets of benefits over $\$ 25,000$ if the offset does not reduce the judgment by more than fifty percent); MO. ANN. STAT. $\$ 490.715$ (West Supp. 2006) (modifying the collateral source rule to allow the introduction of the amount paid by a third party but not the name of such third party); MONT. CODE ANN. § 27-1-308 (2005) (permitting admissibility of collateral source payments made by a third party when the total award is more than $\$ 50,000$, unless the third party has a right to subrogation). These states have responded to a perceived medical malpractice crisis. See Narayen v. Bailey, 747 A.2d 195, 201 (Md. Ct. Spec. App. 2000) ("In response to this crisis, many states enacted legislation to modify or abrogate the collateral source rule in medical malpractice cases."). Additionally, New Jersey has abrogated the rule, except in cases of workers' compensation and life insurance. N.J. STAT. ANN. § 2A:15-97 (West 2000).

6. The following states have entirely abrogated their collateral source rules: Alabama (ALA. CODE $§ 6-5-545$ (2005)), Alaska (Alaska STAT. § 09.17.070 (2004)), Colorado (Colo. Rev. STAT. $\S 13-21-111.6$ (2004)), Connecticut (CONN. GEN. STAT. ANN. § 52-225a (West 2005)), Florida (FLA. STAT. ANN. § 768.76 (West 2005)), Idaho (IDAHO CODE ANN. § 6-1606 (2004)), Indiana (IND. CODE ANN. § 34-44-1-2 (LexisNexis 1998)), Iowa (IowA CoDE ANN. § 668.14 (West 1998)), Michigan (Mich. Comp. LaWs ANN. § 600.6303 (West 2000)), Minnesota (MinN. STAT. ANN. § 548.36 (West 2000)), New York (N.Y. C.P.L.R. 3101(f) (McKinney 2005)), North Dakota (N.D. CENT. CoDE $\S$ 32-03.2-06 (1996)), Ohio (OHIO REV. CODE ANN. § 2315.20 (LexisNexis 2005)), and Oregon (OR. REV. STAT. § 31.580 (2005) (formerly § 18.580; renumbered 2003)).

7. For example, the New Hampshire Supreme Court found unconstitutional a statute that abolished the New Hampshire collateral source rule. Carson v. Maurer, 424 A.2d 825, 836 (N.H. 1980), noted in Am. Tort Reform Ass'n, New Hampshire Reforms, http://www.atra.org/states/NH (last visited Feb. 26, 2006). The Georgia Supreme Court held that a statute abrogating the rule violated the Georgia Constitution. Denton v. Con-Way S. Express, Inc., 402 S.E.2d 269, 272 (Ga. 1991), overruled on other grounds by Grissom v. Gleason, 418 S.E.2d 27 (Ga. 1992), as recognized in McKin v. Gilbert, 432 S.E.2d 233, 235 (Ga. Ct. App. 1993). Kentucky followed Georgia's lead. O'Bryan v. Hedgespeth, 892 S.W.2d 571, 578 (Ky. 1995). Kansas courts have invalidated similar statutes in three situations. See infra Part II.B.3 (discussing the Kansas legislature's three failed attempts to abrogate the collateral source rule).

8. William E. Westerbeke \& Stephen R. McAllister, Survey of Kansas Tort Law: Part I, 49 U. KAN. L. REV. 1037, 1110 (2001).

9. Economic damages, as opposed to noneconomic damages, “"include the cost of medical care, past and future, and related benefits, i.e., lost wages, loss of earning capacity, and other such losses." Shirley v. Smith, 933 P.2d 651, 657 (Kan. 1997) (quoting Shirley v. Smith, 916 P.2d 730, 733 (Kan Ct. App. 1996)). 
behalf. $^{10}$ Generally, courts apply the rule where a third party makes a gratuitous payment or an insurance company pays medical expenses on behalf of the plaintiff. ${ }^{11}$

Insurance and government benefits have significantly complicated the collateral source rule's application; ${ }^{12}$ their establishment has led courts to inconsistently apply the rule where Medicare, Medicaid, or private insurance companies have contracted for a write-off with medical service providers. ${ }^{13}$ In these write-off agreements, medical service providers write off a contractually agreed-upon amount, and Medicare, Medicaid, or the private insurance company pays only a portion of the original amount billed by the medical service provider. ${ }^{14}$ Thus, an issue remains unanswered: Does the collateral source rule limit the plaintiff to economic damages equal to the amount paid ${ }^{15}$ by Medicaid or Medicare, or does it entitle the plaintiff to the amount originally billed by the medical service provider? ${ }^{16}$ Plaintiffs and defendants steadfastly argue

10. Young, supra note 3, at 135.

11. 25 C.J.S. Damages $\S 172-73$ (2002).

12. See Koffman v. Leichtfuss, 630 N.W.2d 201, 208 (Wis. 2001) ("Pursuant to [negotiated and contracted discounts], an insurer's liability for the medical expenses billed to its insured is often satisfied at discounted rates, with the remainder being 'written-off' by the health care provider.").

13. Compare Bynum v. Magno, 101 P.3d 1149, 1157 (Haw. 2004) (noting that the collateral source rule entitles plaintiffs to receive the amount paid by the insurer and the written-off amount), with Moorhead v. Crozer Chester Med. Ctr., 765 A.2d 786, 790 (Pa. 2001) (capping plaintiff's economic damages at the amount actually paid by the insurance company to the medical service provider).

14. See, e.g., Rose v. Via Christi Health Sys., Inc. (Rose I), 78 P.3d 798, 800 (Kan. 2003) ("Medicare fully paid for [the patient's] medical expenses in accordance with its payment contract with [the medical service provider], which required [the medical service provider] to write off $\$ 154,193.24$ of the $\$ 242,104.84$ that it billed."), modified on reh'g, 113 P.3d 241 (Kan. 2005). See infra Part II.A.2 for an example of the collateral source rule's applicability to Medicare write-offs.

15. For purposes of clarity, this Comment attempts to use two terms to refer to the possible amounts recoverable by plaintiffs in this scenario. First, the plaintiff may recover the "actual amount paid" by his or her medical service provider or $\$ 35,000$. Second, the plaintiff may recover the "original amount billed" by his or her medical service provider or $\$ 50,000$.

16. See Rose I, 78 P.3d at 802 (noting that the defendant argued the "trial court should have limited the evidence of medical expenses to those amounts actually paid, without including the amounts it wrote off'). Cases where the tortfeasor is both the defendant and the medical service provider further complicate a court's ability to allocate damages under the collateral source rule and write-off frameworks. Usually, this occurs when the plaintiff is injured due to the medical service provider's negligence. E.g., id. at 806 (Luckert, J., dissenting) (noting that where the tortfeasor is the medical service provider, the collateral source cannot be "wholly independent of and collateral to the wrongdoer"). In these cases, both the defendant and the plaintiff have contracted with Medicare or Medicaid. The defendant hospital's contract establishes a fee schedule by which the medical service provider agrees to charge Medicare or Medicaid, and the plaintiff's insurance contract entitles the plaintiff to the benefits contracted for by the defendant. This Comment does not address this specific issue: the rule's purposes do not apply to this situation, and the Kansas Supreme Court has already settled it. See Rose v. Via Christi Health Sys., Inc. (Rose II), 113 P.3d 241, 248 (Kan. 2005) (holding that where the tortfeasor is both the defendant and the medical service provider, the trial court may allow "a setoff or credit against the portion of the economic loss attributable to 
that a ruling against one will constitute a windfall for the other. Tortfeasors typically stress that courts must not allow plaintiffs to receive write-offs because no one has incurred the costs. Generally, the plaintiff responds that courts relieving tortfeasors from liability effectively grant tortfeasors undeserved windfalls. ${ }^{17}$

The Kansas collateral source rule's application to write-offs has particularly confused practitioners. ${ }^{18}$ Seeking to clarify this murky area of the law, the Kansas legislature recently attacked the rule for a fourth time. ${ }^{19}$ Had Senate Bill $335^{20}$ passed, Kansas would have become the fifteenth state to eradicate its rule. ${ }^{21}$ Although the bill did not survive legislative muster ${ }^{22}$ at least one commentator has questioned the bill's practicality and constitutionality. ${ }^{23}$ Regardless, Kansas's legislative and judicial struggles with "write-off law" offer important lessons for both future Kansas legislation and states considering action in this area.

This Comment strives to learn from these lessons. Part II describes related legal concepts, ${ }^{24}$ discusses other states' approaches to the writeoff question, ${ }^{25}$ explains the relevant historical background on the Kansas collateral source rule's inception and proposed abrogation, ${ }^{26}$ and illustrates the legal ambivalence of the Kansas collateral source rule's applicability to Medicare and Medicaid write-offs. ${ }^{27}$ Part III applies the

medical expenses in the amount of the Medicare write-off, an amount not paid by the plaintiff, Medicare, or any third party, and which reflected a cost incurred by the defendant").

17. See, e.g., Mobile Infirmary Med. Ctr. v. Hodgen, 884 So. 2d 801, 817 (Ala. 2003) (contrasting these competing arguments). Economic theory underlies the idea that the tortfeasor receives a windfall if the court releases him from liability. RICHARD A. POSNER, ECONOMIC ANALYSIS OF LAW 201 (4th ed. 1992). In theory, deterrence and accountability possess an economic value. Allowing the defendant to escape full liability theoretically results in less deterrence and accountability than the tortfeasor would have otherwise been subject to. Id.

18. See infra Part II.C (explaining the uncertainty in Kansas write-off law).

19. See infra Part II.B.3 (describing the Kansas legislature's three previous attempts to abrogate or modify the collateral source rule); see also infra Part II.B.4 (providing a summary of Senate Bill 335 , which recently attempted to abrogate the Kansas collateral source rule).

20. S. 335, 2005-06 Leg., Reg. Sess. (Kan. 2006).

21. See supra note 6 (listing the fourteen states that have eradicated their collateral source rules).

22. The bill died in committee on May 25, 2006. Kansas Legislature, http:// www.kslegislature.org/legsrv-billtrack/searchBills.do (enter " 335 " as the bill number and click "Get Bill Status") (last visited Sept. 8, 2006). Regardless of Senate Bill 335's failure to survive the legislative process, this Comment argues that the legislature may constitutionally abrogate the rule and provides suggestions for strengthening the bill in light of anticipated constitutional challenges. See infra Part III.D.

23. Young, supra note 3, at 159-73.

24. See infra Part II.A.1.

25. See infra Part II.A.3.

26. See infra Part II.B.

27. See infra Part II.C. 
collateral source rule to Medicare and Medicaid and provides a theoretical framework for courts to analyze the collateral source rule. ${ }^{28}$ Additionally, Part III critically analyzes three general answers developed by sister jurisdictions ${ }^{29}$ and, anticipating further challenges to the collateral source rule, analyzes the constitutionality of a bill abrogating the rule. ${ }^{30}$

Ultimately, this Comment proposes three arguments, all dependent on a single premise: defendant deterrence and accountability constitute the primary policy rationales underlying the Kansas collateral source rule. ${ }^{31}$ First, the rule's twin policies direct courts to apply the collateral source rule to write-offs. ${ }^{32}$ Second, Kansas courts will respect the rule's policies only by adopting a reasonable-value approach and awarding the original amount billed by the medical service provider. ${ }^{33}$ However, this does not imply the Kansas Constitution necessarily shields the rule ${ }^{34}$ hence this Comment's last argument: contrary to many commentators' opinions, an attempt to abrogate the Kansas rule may withstand constitutional scrutiny under a rational basis standard of review. ${ }^{35}$ Leaving the rule's fate to a political process not necessarily obstructed by the Kansas Constitution, the Kansas legislature can in fact decide whether its collateral source rule stays or goes.

\section{BACKGROUND}

A brief history of the collateral source rule helps one understand how the establishment of government benefits and private insurance, especially the consequent write-offs from medical service providers, has

28. See infra Part III. Some courts have drawn this line. See, e.g., Robinson v. Bates, 828 N.E.2d 657, 665-69 (Ohio Ct. App. 2005) (compiling case law from several jurisdictions recognizing the statute distinction), discretionary appeal accepted, 835 N.E.2d 381 (Ohio 2005). However, none has provided a policy-driven rationale specifically tying the collateral source rule's deterrent and punitive policies to write-offs. Moreover, this Comment seeks to address Kansas jurisprudence and to reject the payment/nonpayment distinction upon which too many courts have been fixated.

29. See infra Part III.B.

30. See infra Part III.C.

31. See infra Part II.B.2.

32. See infra Part III.A.2.

33. See infra Part III.B (arguing that courts may respect the collateral source rule's policies only if they award plaintiffs the original amount paid by the medical service provider as the reasonable value of their services).

34. A commentator has recently reached the opposite conclusion. See Young, supra note 3, at 167-69 (stating "an abrogation of the collateral source rule, no matter how presented, will violate the Kansas Constitution").

35. See infra Part III.C. 
complicated economic damages. In addition to providing such a history ${ }^{36}$ this Part discusses the necessary background for understanding write-offs ${ }^{37}$ and surveys the analytical frameworks adopted by sister jurisdictions in their struggles with the write-off problem. ${ }^{38}$ Finally, attempting to elucidate the dilemma faced by Kansas lawmakers, this Part exposes the ambivalence in Kansas case law that purports to address the collateral source rule's applicability to write-offs. ${ }^{39}$

\section{A. Write-Offs 101: Relevant Principles, the Problem, and Proposed Solutions}

1. Medicare, Medicaid, and Subrogation

\section{a. Medicare and Medicaid Premiums}

Write-off analysis partially depends on whether the government benefits provider, in this case Medicare or Medicaid, charges premiums to its beneficiary. Medicare is composed of four parts: Hospital Insurance (Part A), Medical Insurance (Part B), Medicare Advantage (Part C), and prescription drug coverage (Part D). ${ }^{40}$ Insureds do not pay premiums for Part A. ${ }^{41}$ In contrast, Part B, C, and D beneficiaries generally pay for their services with monthly premiums. ${ }^{42}$ Insureds may not have to pay premiums if they receive Medicare and possess "limited monthly income," 43 in which case the state may pay their premiums or, in limited situations, even pay their entire deductibles and other medical

36. See infra Part II.B (addressing the inception and the attempted modifications of the Kansas collateral source rule).

37. See infra Part II.A.1 (discussing Medicare and Medicaid premiums and subrogation).

38. See infra Part II.A.3 (providing background on the three approaches used by other jurisdictions).

39. See infra Part II.C (narrating and attempting to synthesize relevant Kansas case law).

40. Social Security Online, http://www.ssa.gov (select "Medicare" from the "Frequently Asked Questions" pulldown menu and click "Go"; then follow "What are the differences between Medicare Parts A, B, C, and D?" hyperlink) (last visited Sept. 26, 2006).

41. See id. ("Part A is paid for by a portion of social security tax."). But see Hodge v. Middletown Hosp. Ass'n, 581 N.E.2d 529, 532-33 (Ohio 1991) (awarding amount under Part A in medical malpractice suit and holding Part A falls under the definition of insurance because it is funded by payments from employer and employee paychecks).

42. Social Security Online, supra note 40.

43. Social Security Online, http://www.ssa.gov (select "Medicare" from the "Frequently Asked Questions" pulldown menu and click "Go"; then follow "Is it true that you can get help paying Medicare premiums?" hyperlink) (last visited Sept. 26, 2006). 
expenses. $^{44}$ Medicare beneficiaries may choose from different plans, all varying in costs and services. ${ }^{45}$

Medicaid, on the other hand, is a state-federal program through which the federal government grants funds to states to aid the poor, elderly, and disabled with medical expenses. ${ }^{46}$ In Kansas, Chapter 39 of the Kansas Statutes Annotated governs Medicaid. ${ }^{47}$ Although certain individuals pay a nominal fee for Medicaid benefits, ${ }^{48}$ most beneficiaries do not pay premiums. ${ }^{49}$

Premiums comprise only part of the equation. Subrogation allows Medicare and Medicaid to recover payments made on behalf of their beneficiaries. Thus, a broader comprehension of the framework underlying write-offs partially depends on an understanding of subrogation. ${ }^{50}$

\section{b. Subrogation}

An insurer's payment of a claim for damages caused by a third party entitles the insurer to subrogation. ${ }^{51}$ Through subrogation, a third party pays the plaintiff's debt and then "receives" the plaintiff's rights and remedies. ${ }^{52}$ Three rationales underlie this insurance doctrine: indemnity

44. See id. ("[The insured's] state may help [the insured] with [the insured's] Medicare and may also pay Medicare deductibles and coinsurance amounts.").

45. See Ctrs. For Medicare \& Medicaid Servs., U.S. DeP'T Of Health \& Human Servs., CMS PUB. NO. 10050, MEDICARE \& YOU 2006, at 37 (2006), available at http://www.medicare.gov/ Publications/Pubs/pdf/10050.pdf (explaining that the amount an insured pays depends partly on whether the plan he or she chooses has a premium in addition to the standard Medicare monthly premium).

46. Harvey L. McCormick, Medicare and Medicaid Claims AND Procedures $§ 22: 1$ (4th ed. 2005) (citing 42 U.S.C.A. $\$ 1396$ ).

47. See KAn. StAT. ANN. $\S \S 39-701$ to -784 (2000 \& Supp. 2005) (providing the legal framework of Kansas Medicaid).

48. Rose v. Via Christi Health Sys., Inc. (Rose I), 78 P.3d 798, 803 (Kan. 2003), modified on reh'g, 113 P.3d 241 (Kan. 2005).

49. See Hodge v. Middletown Hosp. Ass'n, 581 N.E.2d 529, 532 (Ohio 1991) ("Neither the beneficiary nor [the beneficiary's] employer pays premiums or underwrites the cost of the [Medicaid] program.').

50. See infra Part II.A.2 (illustrating the interplay between subrogation and the collateral source rule as it applies to Medicare write-offs).

51. ERic Mills Holmes, Holmes’ ApPleman On Insurance 2D $§ 141.1[\mathrm{~A}]$ (2d ed. 2003).

52. Id. An example should clarify this principle. Assume defendant, D, negligently caused an accident and injured plaintiff, P. P's medical expenses amount to $\$ 100,000$, and P's insurance company pays the full amount. Through subrogation, D (or D's insurance company) now owes $\$ 100,000$ to $\mathrm{P}$ 's insurance company, not to $\mathrm{P}$. Thus, $\mathrm{P}$ 's insurance company is the subrogee, and $\mathrm{P}$ is the subrogor. When P's insurance company pays P's medical expenses, P's insurance company acquires P's right to collect the money from D. 
preservation, ${ }^{53}$ double recovery prevention, ${ }^{54}$ and tortfeasor accountability. ${ }^{55}$ In the medical insurance context, ${ }^{56}$ the insurer's right to exert this principle depends on a policy provision providing for subrogation. However, unlike private insurance, the controlling statutes of Medicare and Medicaid grant these programs an automatic right of subrogation. ${ }^{57}$

\section{The Problem}

To illustrate the issue addressed by this Comment, assume a tortfeasor negligently injures a plaintiff, and the plaintiff consequently incurs medical expenses. The medical service provider initially bills the plaintiff $\$ 50,000$. The plaintiff is a beneficiary of Medicare, and this program previously negotiated a $\$ 15,000$ write-off with the medical service provider for the plaintiff's services. Thus, the actual amount paid by Medicare to the medical service provider is $\$ 35,000$. The plaintiff then sues the tortfeasor asserting economic damages of $\$ 50,000$, the amount originally billed by the medical service provider. Medicare reserves a statutory right to subrogate the amount actually paid, $\$ 35,000$. $^{58}$ At issue is thus whether the tortfeasor will bear the additional $\$ 15,000$ burden or whether the court will allow the tortfeasor to introduce evidence of the $\$ 15,000$ write-off to effectively limit the plaintiff's damages to $\$ 35,000$.

If the court allows the plaintiff to receive the $\$ 15,000$ write-off, then the $\$ 15,000$ burden falls on the defendant. Although the plaintiff pockets $\$ 15,000$, the court subjects the defendant to the full extent of his liability.

53. Id. $\S 141.1[\mathrm{D}][1]$. Most insurance contracts are indemnity contracts; if insureds receive more than what they lost, they might be encouraged to incur losses. Id.

54. Id. $\S 141.1[\mathrm{D}][2]$. Subrogation effectively eliminates the possibility that the insured might receive a windfall. See $i d$. ("The policy underlying subrogation is to prevent an unwarranted windfall to the insured.").

55. Id. $\S 141.1[\mathrm{D}][3]$. Subrogation "ensures that the person who in good conscience ought to pay a loss (the tortfeasor) does in fact pay the loss." Id.

56. The author does not attempt to distinguish between legal and contractual subrogation because "most insurance policies include subrogation provisions," so the distinction between legal and contractual generally is legally irrelevant. Id. § 141.2[C][2].

57. See Gary D. White, Jr., Practitioner's Guide to Subrogation Liens and Reimbursement Rights, J. KAN. TRIAL LAW. ASS'N, Mar. 1995, at 5, 5 ("When Medicare has paid benefits and a third party is responsible for the injury, Medicare has a subrogation right to the extent it has paid benefits." (citing 42 U.S.C. $\$ 1395(y)(b)(2)(B) ; 42$ C.F.R. $\$ 411.26)$ ). The Deficit Reduction Act of 1984, 42 U.S.C. $§ 1395(y)(b)(2)(B)(i v)$, provides "the United States will be subrogated (to the extent Medicare payment has been made for an item or service) to any right of an individual." MCCORMICK, supra note 46, § 1:72. Similarly, the state of Kansas retains an automatic right of subrogation in cases involving Medicaid. KAN. STAT. ANN. § 39-719a (2005).

58. White, supra note 57 , at 5. 
Conversely, if the court permits the defendant to introduce evidence of the write-off, then the court presumably relieves the defendant from $\$ 15,000$ worth of liability. The practical result in this second scenario is the following: the plaintiff pockets nothing, and the court holds the defendant fully liable for the damages he would have caused but for the plaintiff's contractual agreement with Medicare or Medicaid. ${ }^{59}$

Not surprisingly, this scenario has met significantly inconsistent applications across, and even within, ${ }^{60}$ jurisdictions. If Louisiana law governs, the court will likely award the plaintiff the $\$ 15,000$ because he, theoretically, bargained for the Medicare benefits. ${ }^{61}$ In contrast, had the plaintiff been a Medicaid beneficiary, the court would not have awarded him the write-off, reasoning that he never bargained for the benefit. ${ }^{62}$ In Hawaii, the plaintiff would receive the original amount billed by the medical service provider - the program at issue is irrelevant. ${ }^{63}$ Similarly, states that have abrogated their collateral source rules would likely allow the tortfeasor to introduce evidence of the write-off, regardless of whether Medicare or Medicaid write-offs are at issue. ${ }^{64}$ Kansas adds to this uncertainty: the uncertain legal relevance of the government benefits at issue and the Kansas collateral source rule's applicability produced a cacophony of results. ${ }^{65}$

\section{Three Proposed Solutions}

While a look at other jurisdictions' rules may not per se settle this quandary, an exposition of other jurisdictions' approaches to this problem helps Kansas tailor an appropriate rule. With this purpose in

59. Either way, Medicare is at a $\$ 0$ balance because it automatically subrogates the $\$ 35,000$ paid by the defendant. See supra Part II.A.1.b (discussing subrogation principles as applicable to Medicare and Medicaid).

60. See, e.g., infra Part II.C (exploring the uncertainty in Kansas law regarding Medicare and Medicaid write-offs).

61. See infra Part II.A.3.a (explaining the benefit-of-the-bargain approach).

62. See infra notes 231-37 and accompanying text (noting that, in jurisdictions utilizing the benefit-of-the-bargain approach, Medicare beneficiaries, but not those covered by Medicaid, generally receive the write-off because they have paid premiums for the coverage).

63. See supra note 3 (noting the Hawaii collateral source rule does not allow courts to undercut plaintiffs' damages with evidence of collateral sources); see also infra note 92 (noting one may reasonably refer to Hawaii write-off law as the "full amount" approach).

64. See, e.g., Goble v. Frohman, 901 So. 2d 830, 832-33 (Fla. 2005) (prohibiting recovery of private insurance write-offs, in part because of FLA. STAT. § 768.76 (1999), which orders courts to reduce awards by the collateral source benefits); Dyet v. McKinley, 81 P.3d 1236, 1238-39 (Idaho 2003) (limiting recovery to the actual amount paid by Medicare and considering IDAHO CODE ANN. § 6-1606 (2003), which prohibits double recoveries from collateral sources).

65. See infra Part II.C (discussing the obscurity in Kansas law regarding write-offs). 
mind, this Subpart outlines the three prevalent approaches utilized by sister jurisdictions: benefit-of-the-bargain, ${ }^{66}$ actual-amount-paid, ${ }^{67}$ and reasonable-value. ${ }^{68}$

\section{a. Benefit-of-the-Bargain Approach ${ }^{69}$}

The benefit-of-the-bargain approach allows a plaintiff to recover the full value of her medical expenses, including the write-off, if she has paid consideration for her benefit. ${ }^{70}$ Bozeman $v$. State ${ }^{71}$ provides an example. There, the Louisiana Supreme Court held that a Medicaid recipient could not collect Medicaid write-offs because he had neither personally bargained for the benefit nor paid the premiums. ${ }^{72}$ In contrast, plaintiffs who have bargained for insurance enjoy entitlement to the benefit of their bargain and may recover the original amount billed by their medical service provider. ${ }^{73}$

This rendition of the benefit-of-the-bargain approach oversimplifies its nature. Courts adopting this rationale significantly differ in the approach's implementation. The differences arise from the courts' perspectives of Medicare and Medicaid requirements; the key here is the court's view of whether the plaintiff actually paid any consideration for either of these two programs. Subscribing to this approach, for example, the Commonwealth of Virginia ${ }^{74}$ awards private insurance write-offs to plaintiffs because of their presumed bargains with their insurance companies. $^{75}$ The Kansas Supreme Court extended this reasoning to Medicare write-offs in Rose v. Via Christi Health Systems, Inc. $($ Rose I)

66. See infra Part II.A.3.a (discussing the benefit-of-the-bargain approach).

67. See infra Part II.A.3.b (discussing the actual-amount-paid approach).

68. See infra Part II.A.3.c (discussing the reasonable-value approach).

69. The author borrows the names of these three approaches from Bozeman v. State, 879 So. $2 \mathrm{~d}$ 692, 701-05 (La. 2004).

70. Id. at 702

71. Id. at 706 .

72. Id.; see also supra note 49 and accompanying text (noting that Medicaid recipients generally do not pay premiums).

73. Bozeman, 879 So. $2 \mathrm{~d}$ at 706.

74. See Acuar v. Letourneau, 531 S.E.2d 316, 322 (Va. 2000) (justifying the plaintiff's recovery of the write-off by explaining "those amounts written off are as much of a benefit for which [the plaintiff] paid consideration as are the actual cash payments made by his health insurance carrier to the health care providers").

75. Id. at 323

76. 78 P.3d 798, 806 (2003), modified on reh'g, 113 P.3d 241 (Kan. 2005). The Kansas Supreme Court subsequently modified Rose I; in its new 2005 decision, the court did not consider whether a plaintiff who pays premiums for Medicare benefits is entitled to receive the benefit of his bargain. See infra note 193 (discussing Rose II). 
and concluded that plaintiffs who pay premiums for Medicare benefits are entitled to the benefit of their bargain. ${ }^{77}$

The Kansas District Court adopted the opposite extreme in Wildermuth $v$. Staton. ${ }^{78}$ That case presented the issue of whether plaintiffs are entitled to Medicare benefits. ${ }^{79}$ Although beneficiaries generally pay a premium for Medicare benefits, ${ }^{80}$ the court allowed the defendants to introduce evidence of the write-off, thereby effectively limiting the plaintiff's recovery to the actual amount paid by Medicare. The court reasoned that the write-offs did not constitute a benefit the plaintiffs personally obtained or for which they individually bargained. ${ }^{81}$ Instead, according to the court, federal law required the write-offs, and Medicare law and regulations prohibit medical service providers from seeking reimbursement for the write-offs from anyone. ${ }^{82}$ Thus, the court refused to award the Medicare write-off to the plaintiff. ${ }^{83}$

\section{b. Actual-Amount-Paid Approach}

Courts generally offer two reasons for allowing defendants to introduce evidence of write-offs. First, because neither the plaintiff nor anyone else incurred the cost of the write-offs, the defendant ought to not incur the loss. Expanding on this point, a Kansas court opined that allowing the plaintiff to receive the write-off is to fabricate a false presumption that the write-off constitutes a "payment." 84 Second,

\footnotetext{
77. Rose I, 78 P.3d at 806.

78. No. Civ. A. 01-2418-CM, 2002 WL 922137 (D. Kan. Apr. 29, 2002).

79. Id. at $* 3$.

80. See supra note 42 and accompanying text (noting that Medicare Part B beneficiaries generally pay premiums for their benefits).

81. Wildermuth, 2002 WL 922137 , at $* 5$.

82. Id. at *13-14.

83. Id. The Ohio Supreme Court reached an even more surprising result in Hodge v.
} Middletown Hospital Ass' $n, 581$ N.E.2d 529, 532 (Ohio 1991). The court awarded the write-off in a Medicare Part A case using a benefit-of-the-bargain analysis although Part A beneficiaries do not pay premiums. The court justified its approach by noting the following:

Medicaid payments ... are significantly different from benefits paid as Medicare Part A. Medicaid is a system for providing payment of medical costs to the poor. Neither the beneficiary nor his employer pays premiums or underwrites the cost of the program. . . Payment into the [Medicare] trust fund, though involuntary, is in exchange for health care coverage, and gives rise to a duty on the part of the government to pay benefits when required. In addition, the language of the statute specifically refers to "policy or contract" of insurance. In short, Medicare Part A is funded by payments made by beneficiaries and their employers, is actuarily determined, and is described by its enabling statute as insurance.

Id. at 532-33 (emphasis omitted); see also supra note 49 and accompanying text (citing Hodge).

84. See Liberty v. Westwood United Super, Inc., No. 89,143, 2005 WL 1006363, at *5 (Kan. 
because making the plaintiff whole is the goal of recovery, a write-off award would simply result in an unwarranted windfall to the plaintiff. ${ }^{85}$

U.S. district courts in Kansas have expressly adopted these two rationales. In Wildermuth, a case involving Medicare, the court offered two rationales when rejecting a distinction between Medicare and Medicaid as a basis for allowing the plaintiff to recover the write-off. First, the court emphasized the collateral source rule's language, noting that "the collateral source rule, by its express terms, simply does not apply to write-offs of expenses that are never paid." ${ }^{\prime 6}$ Second, the court justified its approach with the windfall rationale: "allowing a plaintiff to recover the amount of charges written-off would result in a windfall to the plaintiff." ${ }^{, 87}$ Similarly, in Strahley v. Mercy Health Center, ${ }^{88}$ the Kansas District Court concluded plaintiffs cannot recover "losses" incurred by no one. ${ }^{89}$

\section{c. Reasonable-Value Approach}

Reasonableness as a standard has permeated American jurisprudence since its inception, and the collateral source rule has not escaped the standard's reach. In answering the write-off question, several jurisdictions use a reasonable-value approach, through which the court awards plaintiffs only the reasonable value of the medical expenses. ${ }^{90}$

Ascertaining the definition of "reasonable value" presents the most troubling question regarding this approach. ${ }^{91}$ Courts primarily interpret this term of art in three fashions. First, the reasonable value of the services represents the full amount of the services, including the write-

Ct. App. Apr. 29, 2005) ("The application of [the collateral source] rule to mandatory Medicare discounts requires a great deal of creativity. ... [O]ne must fictionally characterize the mandatory contractual discount for Medicare patients as a 'payment' of medical expenses. . . . No one is paid the discount ....").

85. See Bozeman v. State, 879 So. 2d 692, 702 (La. 2004) (discussing various courts' use of this approach).

86. Wildermuth, 2002 WL 922137 , at $* 5$.

87. Id.

88. No. Civ. A. 99-2439-KHV, 2000 WL 1745291 (D. Kan. Nov. 9, 2000).

89. Id. at $* 2$.

90. See, e.g., Bynum v. Magno, 101 P.3d 1149, 1157-60 (Haw. 2004) (applying the reasonablevalue standard); Haselden v. Davis, 579 S.E.2d 293, 295 (S.C. 2003) (noting a defendant who agrees to be a Medicaid provider and bills a Medicaid patient for the full value of the services "may not claim that the true, reasonable value of those services is the lesser amount paid by Medicaid. Accordingly . . . the amount billed by [a Medicaid provider is] relevant to establish the reasonable value of the services provided ....”); Koffman v. Leichtfuss, 630 N.W.2d 201, 209 (Wis. 2001) ("[W]hile the actual amount paid for medical services may reflect the reasonable value of the treatment rendered, the focus is on the reasonable value, not the actual charge.").

91. Bynum, 101 P.3d at 1155 . 
offs. ${ }^{92}$ Second, converse to the first variation, the reasonable value of the services does not include the write-off. ${ }^{93}$ Third, both the amounts originally billed by the medical service provider and actually paid by the insurance company help fact finders calculate the reasonable value of the plaintiff's medical expenses. ${ }^{94}$

\section{B. The Collateral Source Rule}

Having outlined the intricacies and relevant considerations of the write-off issue, this Subpart in part provides information necessary to understand whether the collateral source rule even applies to write-offs. This Subpart begins with the rule's history ${ }^{95}$ and subsequently describes the Kansas legislature's attempts to modify and abrogate the collateral source rule. ${ }^{96}$ An understanding of the rule's beginnings and its troubled history is vital to a sound constitutional analysis of the Kansas legislature's attempts to abrogate the collateral source rule.

\section{Inception: A Focus on the Rule's Rationales}

Harding v. Town of Townsend ${ }^{97}$ gave birth to the term "collateral source." 98 Scholars nonetheless generally trace the concept's inception to Propeller Monticello v. Mollison, ${ }^{99}$ a seminal mid-nineteenth-century

92. See id. at 1161 (holding plaintiffs are entitled to recover the reasonable value of the medical services, and that this is the amount paid by the insurance company plus the write-off). Perhaps, Bynum ought to be referred to as a "full-amount" approach. The decision adduces two persuasive arguments. First, the court used a syllogism: the collateral source rule allows plaintiffs to recover gratuitous payments; the write-off is a gratuitous payment by the physician to the plaintiff; therefore, the plaintiff should recover the write-off. Id. at 1156. Second, the court explained that "no precedent is overturned inasmuch as the issue at hand has not been decided in this jurisdiction. Indeed, none of the parties argue that a decision such as this one, consistent with other decisions reaching the same or similar results, would result in overturning Hawai'i law." Id. at $1160 \mathrm{n} .24$

93. See, e.g., Hanif v. Hous. Auth., 246 Cal. Rptr. 192, 193-97 (Cal. Ct. App. 1988) (holding the amount paid by Medicaid caps the reasonable value of the medical services).

94. See, e.g., Haselden, 579 S.E.2d at 295 ("[W]e hold the amount billed by [the defendant] was relevant to establish the reasonable value of the services provided to Hill."); see also Iles v. Autozone Stores, Inc., 12 F. App’x 627, 631 (10th Cir. 2001) ("[T]he collateral source rule is a substantive state rule of evidence ....").

95. See infra Part II.B.1 (discussing the collateral source rule's history).

96. See infra Part II.B.3.

97. 43 Vt. 536 (1871).

98. See Baptist Healthcare Sys., Inc. v. Miller, 177 S.W.3d 676, 687 (Ky. 2005) (citing Harding) ("The policy of insurance is collateral to the remedy against the defendant, and was procured solely by the plaintiff at his expense, and to the procurement of which the defendant was in no way contributory.").

99. 58 U.S. 152, 155 (1854); see also Douglas H. Schwartz, Comment, The Tortured Path of Ohio's Collateral Source Rule, 65 U. CIN. L. REV. 643, 643 (1997) (tracing the collateral source rule 
Supreme Court of the United States decision in which the Court reasoned that a tortfeasor should not benefit from an injured party's insurance benefits. ${ }^{100}$ "[R] egardless of the victim's access to insurance benefits," the Court "bound [the defendant] to make satisfaction for the injury."101

Although most jurisdictions subsequently embraced this ruling, ${ }^{102}$ courts have often adopted various rationales to explain the collateral source rule. According to some jurisdictions, the rule applies because courts should not force plaintiffs to transfer to tortfeasors the benefit of their bargain. ${ }^{103}$ The Tenth Circuit recognizes two additional rationales. First, if either a windfall must fall on the tortfeasor or the plaintiff must receive a double recovery, then public policy demands that courts not reward the tortfeasor for the plaintiff's good fortune. ${ }^{104}$ Second, the rule encourages maintenance of insurance by assuring plaintiffs' payments from collateral sources will not be reduced. ${ }^{105}$ Most important for purposes of this Comment's thesis, other courts emphasize the collateral source rule's deterrent value. ${ }^{106}$

2. From Fairness to Deterrence and Accountability: The Prevalent Kansas Rationales

The Kansas Supreme Court first recognized the collateral source rule in Berry v. Dewey. ${ }^{107}$ Berry involved a wrongful death action brought by a mother who received a financial benefit resulting from her son's death. ${ }^{108}$ The defendant argued that the trial court should have deducted the benefit from the verdict. ${ }^{109}$ Upholding the damages amount, the court called the defendant's argument "untenable"110 and reasoned, without

back to Propeller Monticello v. Mollison).

100. See Propeller Monticello, 58 U.S. at 155 ("The defence set up in the answer, that the libellants have received satisfaction from the insurers, cannot avail the respondent. The contract with the insurer is in the nature of a wager between third parties, with which the trespasser has no concern.").

101. Schwartz, supra note 99 , at 643 .

102. Id.

103. Amwest Sav. Ass'n v. Statewide Capital, Inc., 144 F.3d 885, 889 (5th Cir. 1998) (citing RESTATEMENT (SECOND) OF TORTS $§ 920 A$ cmt. c. (1979)).

104. Green v. Denver \& Rio Grande W. R.R. Co., 59 F.3d 1029, 1032 (10th Cir. 1995) (citing FDIC v. United Pac. Ins. Co., 20 F.3d 1070, 1083 (10th Cir. 1994)).

105. Id. (citing Quinones v. Pa. Gen. Ins. Co., 804 F.2d 1167, 1171 (10th Cir. 1986)).

106. See Bozeman v. State, 879 So. 2d 692, 700 (La. 2004) ("The underlying concept is that tort damages can help to deter unreasonably dangerous conduct.").

107. 172 P. 27 (Kan. 1918).

108. Id. at 28 .

109. Id.

110. Id. at 29 . 
further explanation, that the proposition "does not address itself to the judgment of this court as being sound, legal, equitable, or fair." 111 Thus, the Berry court did not adopt deterrence or accountability as the rationales of its decision.

The rationale adopted by Kansas courts has since evolved. Berry began with fairness, though the Berry court itself failed to answer why the collateral source rule produces "fair" results. ${ }^{112}$ Subsequent case law demonstrates the evolution of the fairness rationale. Today, the Kansas collateral source rule's underlying policies are twofold: accountability and deterrence. ${ }^{113}$ The idea that courts must hold the defendant liable for the full amount of damages he causes underlies the accountability policy. ${ }^{114}$ A tortfeasor unjustifiably escapes responsibility unless the collateral source rule holds him accountable. ${ }^{115}$ Kansas courts also generally emphasize the collateral source rule's deterrent value. These courts assume that a tortfeasor's knowledge that the plaintiff's insurance company will pay for the damages may diminish the tortfeasor's incentive to act reasonably. ${ }^{116}$

111. Id. at $29-30$

112. The court did little, if anything, to explain why allowing the defendant to introduce evidence of collateral source payments would be unfair. $I d$.

113. While Kansas courts have not expressly rejected the "maintenance of insurance" rationale advanced by the Tenth Circuit, they have relentlessly relied on deterrence and accountability. See infra notes 114-16 and accompanying text (discussing the twin rationales of the Kansas collateral source rule). This suggests accountability and deterrence constitute the two strongest policies underlying the Kansas collateral source rule.

114. Young, supra note 3, at 138 (citing Bates v. Hogg, 921 P.2d 249, 255 (Kan. Ct. App. 1996) (Rulon, J., dissenting)).

115. Id.

116. Id. Rexroad v. Kansas Power \& Light Co., 388 P.2d 832 (Kan. 1962), is a prime example of the deterrence principle. There, the Kansas Supreme Court reasoned that the defendant could not introduce evidence of insurance benefits because "[t]he question of the right to the proceeds of the recovery is a matter between the insurer and the insured." Id. at 841. The Kansas Supreme Court further explained "the contract of insurance and the subsequent conduct of the insurer and insured in relation thereto are matters with which the wrongdoer has no concern and which do not affect the measure of his liability." Id. at 842 (citing 15 AM. JuR. Damages § 210) (emphasis added). Rexroad's reasoning has since resonated in Kansas jurisprudence. See Zak v. Riffel, 115 P.3d 165, 174 (Kan. Ct. App. 2005) ("The purpose of the collateral source rule is to prevent the tortfeasor from escaping full liability ...."); see also King Grain Co. v. Caldwell Mfg. Co., 820 F. Supp. 569, 573 (D. Kan. 1993) (citing Rexroad, 388 P.2d at 842) ("The Kansas Supreme Court has held that a tort plaintiff's damages are not diminished where the plaintiff is indemnified by insurance."); Allman v. Holleman, 667 P.2d 296, 302 (Kan. 1983) (noting that, in action brought by children for the alleged wrongful death of their mother, " $[t]$ he fact the children received some assistance from another source has nothing to do with the [pecuniary valuation of] services and support provided by [the mother] herself"). 


\section{Abrogation: Unconstitutional Discrimination?}

In response to a perceived nationwide medical malpractice crisis, ${ }^{117}$ the Kansas legislature has repeatedly attempted to modify the Kansas collateral source rule. ${ }^{118}$ It first attempted to modify the rule in $1976 .{ }^{119}$ Section $60-471^{120}$ granted a trier of fact the discretion to balance a reimbursement or indemnification provided by health maintenance organizations and additional evidence. ${ }^{121}$ Two points regarding this statute are worth noting: First, the legislature limited the statute's scope to medical malpractice actions. ${ }^{122}$ Second, the legislature precluded consideration of insurance payments made by the insured or his employer, or by the injured party or his employer. ${ }^{123}$

In Wentling v. Medical Anesthesia Services, ${ }^{124}$ the Kansas Supreme Court declared section 60-471 unconstitutional on equal protection grounds under both the United States and the Kansas Constitutions. ${ }^{125}$ Applying a heightened level of scrutiny, ${ }^{126}$ the court stated that section

117. See Bryan W. Smith, Note, The Medical Malpractice Insurance "Crisis": Did Kansas Tort Reform Really Work?, 31 WASHBURN L.J. 106, 108-09 (1991) (commenting on the perceived medical malpractice crisis); see also Jordyn K. McAfee, Note, Medical Malpractice Crisis Factional or Fictional?: An Overview of the GAO Report as Interpreted by the Proponents and Opponents of Tort Reform, 9 J. MED. \& L. 161, 163 (2005) (questioning the existence of a medical malpractice crisis).

118. See Eaton, supra note 2, at 916-19 (describing the three attempts of the Kansas legislature to modify the collateral source rule).

119. Id. at 916 .

120. KAN. StAT. ANN. $\S \S 60-471(a)-(b)$ (1983) (repealed 1985).

121. See Eaton, supra note 2, at 916 (noting that $\$ 60-471(\mathrm{a})-(\mathrm{b})$ allowed fact finders to accord "such weight as [they should] choose to ascribe to that evidence in determining the amount of damages to be awarded"').

122. Id.

123. Id.

124. 701 P.2d 939 (Kan. 1985).

125. Id. at 951; see also Eaton, supra note 2, at 916 (discussing Wentling).

126. The Kansas Supreme Court applied a heightened level of scrutiny because of the nature of the rights involved. In justifying its choice of constitutional scrutiny, the court gave the following hypothetical about two patients:

One is wealthy, and has insurance, while the other has no resources to pay for medical care and is uninsured. The first is able to retain private nursing care, which is paid for by the insurance, while the second, needing the same continual care, is cared for by his wife, who was forced to quit her job to stay home and care for him. It is said the modified collateral source rule would exclude evidence that the private nursing care for the first patient was in fact paid for by the insurance company, while the jury would be apprised of the fact that the second patient's care was provided free by his wife, and perhaps she had been earning only the minimum wage at the job she left.

Wentling, 701 P.2d at 950 (quoting Doran v. Priddy, 534 F. Supp. 30, 36 (D. Kan. 1981)). However, as infra note 144 and its accompanying text clarify, the Kansas Supreme Court reviewed the writeoff issue under a rational basis standard in the last case on point. This strongly suggests that any attempt by the Kansas legislature to abrogate or modify the rule will be subject to rational basis 
60-471 discriminated in two ways: First, section 60-471 "discriminated among those parties claiming to have been injured by the wrongful conduct of another by treating those allegedly injured by a health care provider differently than those allegedly injured by someone other than a health care provider." ${ }^{\prime 27}$ Also, the statute "discriminated between those who paid for or received by virtue of their employment certain benefits and those who received those benefits gratuitously." 128 The court explained that if in promulgating section 60-471 the legislature " intended to keep down the costs of medical malpractice insurance, and to limit the size of medical malpractice verdicts," $" 129$ the distinction between insured plaintiffs and "'ones who must rely upon kindness for some of their pre-litigation care" "130 did not further that purpose. Rather, it "substantially undermine[d] that purpose . . . at the expense of the indigent litigant" $" 131$ and thus violated the Fourteenth Amendment to the United States Constitution as well as the Kansas Constitution. ${ }^{132}$

Two legislative attacks followed Wentling. In 1985, the Kansas legislature enacted section $60-3403,{ }^{133}$ and, in 1988, the legislature passed sections $60-3801$ to $-3807 .^{134}$ Section $60-3403$ allowed evidence of benefits received by any claimant, including insurance coverage, workers' compensation, and social welfare benefit programs. ${ }^{135}$ The statute also permitted a claimant to present evidence of any amount paid in obtaining those benefits, and "the trier of fact would offset the claimant's expenses against the amount the claimant received from the benefits." " 60-3403 unconstitutional under the Equal Protection Clause of the Kansas Constitution. ${ }^{137}$ In Farley v. Engelken, ${ }^{138}$ the court's rationale clarified the court's firm belief that the statute's distinction between those with and without insurance served only to wrongly discriminate

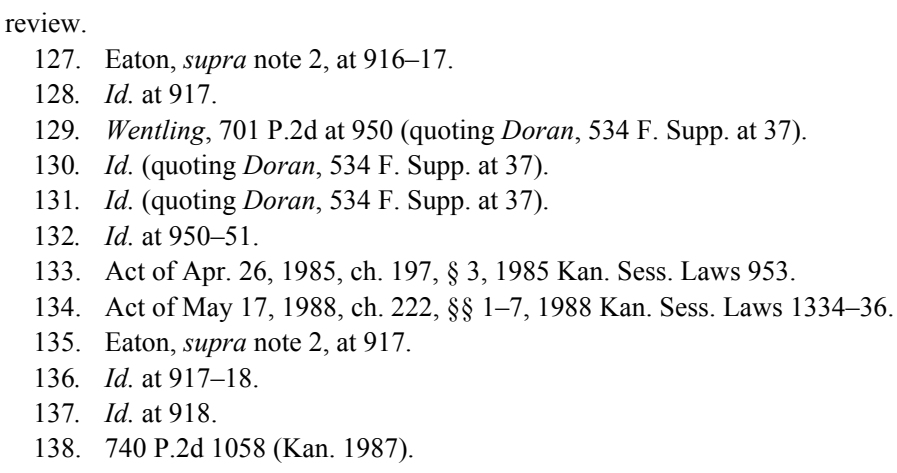


and thus did "not substantially further a legitimate legislative objective." $" 139$

Sections 60-3801 to -3807 encountered a similar fate. According to these statutes, where a personal injury claimant sought more than $\$ 150,000$ in damages, "evidence of collateral source benefits received or evidence of collateral source benefits which are reasonably expected to be received in the future shall be admissible." ${ }^{\text {"140 }}$ Sections 60-3801 to 3807 authorized the claimant to introduce evidence of the cost of the collateral sources and required the trier of fact to reduce the judgment by the amount of the collateral source benefits minus the benefits' cost. ${ }^{141}$

Again, the Kansas Supreme Court, in Thompson v. KFB Insurance Co. ${ }^{142}$ held the statute modifying the rule unconstitutional under the United States and the Kansas Constitutions. ${ }^{143}$ This time using a rational basis standard of review, the court explained that "[e]ven assuming the objective of cutting insurance costs is a legitimate legislative goal, ... the only basis for the $[\$ 150,000]$ classification is to deny a benefit to one group for no purpose other than to discriminate against that group."144 As such, the classification represents an "arbitrary" and thus unconstitutional attempt by the legislature. ${ }^{145}$

\section{Senate Bill 335}

The Kansas legislature recently attempted to abrogate the collateral source rule in all personal injury claims, ${ }^{146}$ a move that could have significantly altered Kansas personal injury law. Section 1 of the bill proposes to abrogate the rule in "any action," regardless of the plaintiff's damages. ${ }^{147}$ Section 2 amends the previous statute to allow, but not require, fact finders to calculate the net collateral source benefits. ${ }^{148}$ If the jury is the fact finder, and the jury makes the calculation, the bill requires the jury to itemize its verdict. ${ }^{149}$ Following this calculation, the

\footnotetext{
139. Eaton, supra note 2, at 918 (citing Farley, 740 P.2d at 1068).

140. KAN. STAT. ANN. § 60-3802 (2005).

141. Eaton, supra note 2, at 919.

142. 850 P.2d 773 (Kan. 1993).

143. Id. at 779 .

144. Id. at 782 .

145. Id.

146. See S. 335, 2005-06 Leg., Reg. Sess. (Kan. 2006) (attempting to remove requirement of $\$ 150,000$ in damages from KAN. STAT. ANN. § 60-3802 (2005)).

147. Id.

148. Id.

149. Id.
} 
bill requires the court to reduce the verdict by the amount of the plaintiff's collateral source benefits. ${ }^{150}$

Although the bill died in committee, its substance begs an important question: Had it passed, would Kansas courts have condoned this legislative effort? One commentator recently attempted to provide answers to these questions. One can summarize her constitutional arguments as follows: even if the legislature had enacted Senate Bill 335, courts would have declared it unconstitutional because abrogation (1) lacks a rational legislative basis absent a medical malpractice crisis, ${ }^{151}$ (2) violates plaintiffs' constitutional right to a remedy, ${ }^{152}$ and (3) infringes upon plaintiffs' equal protection guarantee. ${ }^{153}$

\section{What Kansas Courts Have Not Said About Medicare and Medicaid Write-Offs}

While Kansas legislators struggle with the collateral source rule, Kansas courts attempt to clarify Kansas law on Medicare and Medicaid write-offs. However, these judicial attempts have failed. In Bates v. Hogg ${ }^{154}$ the Kansas Court of Appeals held that, where Medicaid is at issue, plaintiffs are entitled only to receive the actual amount paid to their medical service providers. ${ }^{155}$ Subsequently, the Kansas Supreme Court distinguished Bates from Rose v. Via Christi Health System, Inc. (Rose I), ${ }^{156}$ a 2003 decision noting that plaintiffs are entitled to receive Medicare write-offs because Medicare charges premiums to its beneficiaries. ${ }^{157}$ The court then granted a motion to rehear Rose $I,{ }^{158}$ thus planting the seed for confusion among practitioners.

Before the Kansas Supreme Court reheard Rose I, the Kansas Court of Appeals decided Fischer v. Farmers Insurance Co. ${ }^{159}$ and Liberty v.

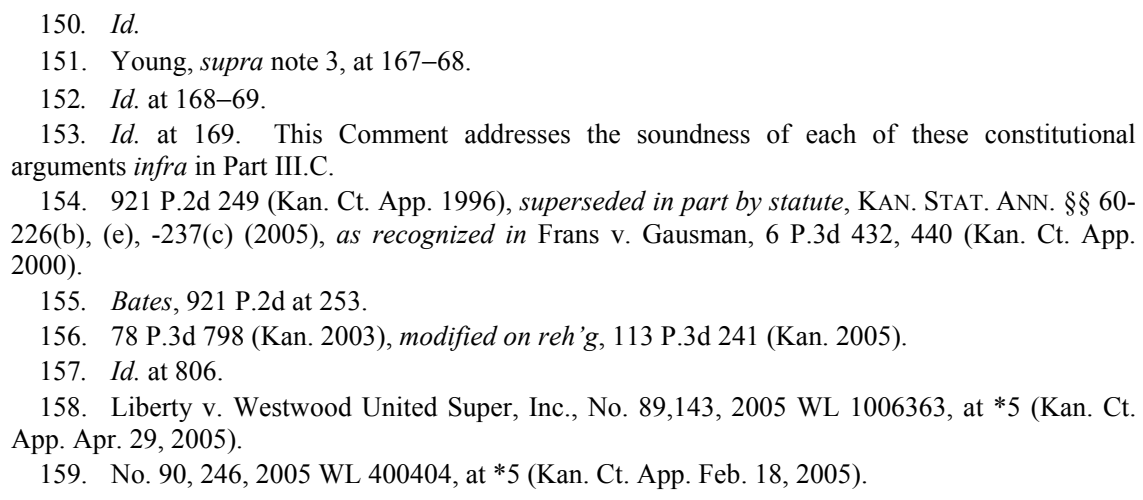


Westwood United Super, Inc. ${ }^{160}$ Noting that through its grant of a motion for rehearing the Kansas Supreme Court had suspended Rose I's precedential value, the Kansas Court of Appeals applied Bates to private insurance benefits. ${ }^{161}$ Similarly, the Liberty court extended Bates to Medicare. ${ }^{162}$ The new Rose v. Via Christi Health Systems, Inc. (Rose II) ${ }^{163}$ decision did little to settle the law. Refusing to settle the discord between Bates, on one hand, and Fischer and Liberty, on the other, the Kansas Supreme Court limited Rose II to cases where the tortfeasor was both the defendant and the medical service provider. ${ }^{164}$

In Bates, the plaintiff and defendant were involved in an accident. ${ }^{165}$ Before trial, the defendant filed a motion in limine seeking to limit the plaintiff's evidence of economic damages to the amount paid by Medicaid on the plaintiff's behalf. ${ }^{166}$ Reversing the trial court's grant of the motion, the appellate court firmly stated the collateral source rule did not apply to Medicaid write-offs. ${ }^{167}$ Instead, because a medical service provider cannot charge Medicaid patients for the write-off, the actual amount paid by Medicaid constitutes the "customary charge" and thus constitutes the only amount recoverable by the plaintiff. ${ }^{168}$

In the Medicare context, the write-off issue first arose in the Rose decisions. Bates and Rose shared similar facts, subject to two main distinctions: Rose involved Medicare, ${ }^{169}$ and the Rose defendant played the roles of both tortfeasor and medical service provider. ${ }^{170}$ In Rose, the decedent injured himself while under the defendant's care. ${ }^{171}$ After this injury, the defendant hospital continued to treat the decedent. ${ }^{172}$ The defendant hospital "billed [the decedent] and his insurer, Medicare, for

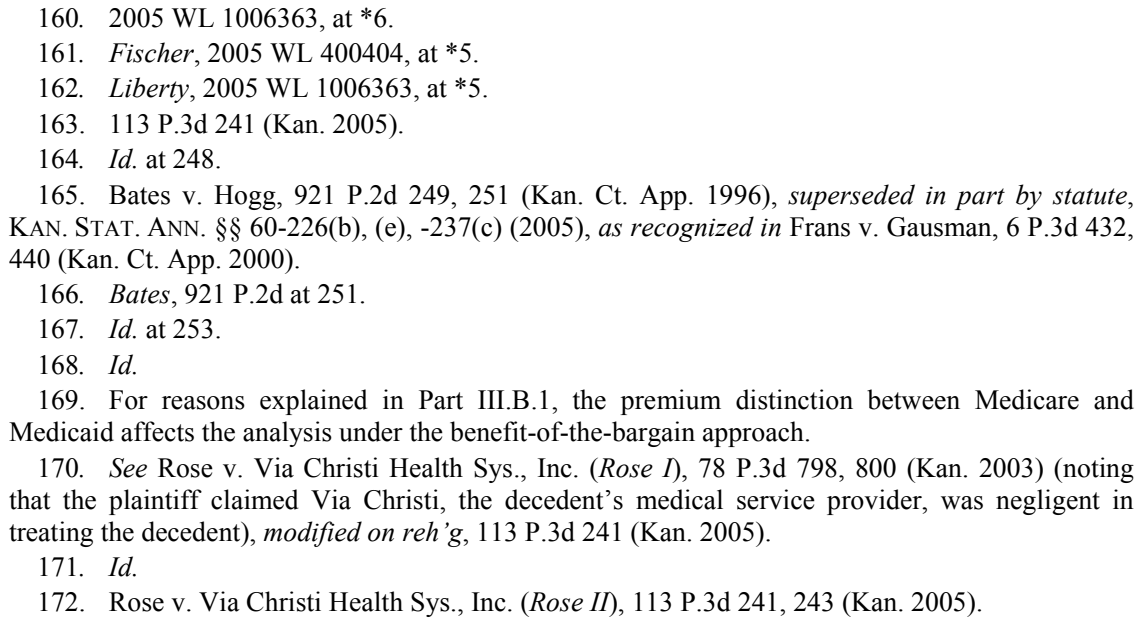


the full cost of [the decedent's] treatment."173 Pursuant to an agreement with Medicare, the defendant hospital wrote off $\$ 154,193.24$ of the $\$ 242,104.84$ it originally billed. ${ }^{174}$ Medicare paid the difference. ${ }^{175}$

At trial, the plaintiff alleged the defendant hospital had been negligent in treating the decedent. ${ }^{176}$ The court held in favor of the plaintiff on the negligence issue. ${ }^{177}$ Similarly, the trial court determined that Bates was inapplicable to Medicare write-offs and admitted into evidence the defendant hospital's initial bill of $\$ 242,104.84 .{ }^{178}$ On appeal, the Kansas Supreme Court considered whether the defendant hospital may introduce evidence of Medicare write-offs. ${ }^{179}$ Distinguishing Rose from Bates (and thus distinguishing Medicare from Medicaid for purposes of write-off analysis), the appellate court held that the plaintiff should receive the write-off because he had bargained for the Medicare benefit. ${ }^{180}$ Thereafter, the Kansas Supreme Court granted a motion to rehear Rose. ${ }^{181}$

Before the Kansas Supreme Court issued its new opinion, a threejudge panel of the Kansas Court of Appeals issued two relevant unpublished decisions: Fischer v. Farmers Insurance Co. ${ }^{182}$ and Liberty v. Westwood United Super, Inc. ${ }^{183}$ In Fisher, the plaintiff sued her private insurance company after an accident in an attempt to recover under her policy's underinsured coverage provision. ${ }^{184}$ Applying Bates, the trial court excluded evidence of the private insurance write-off. ${ }^{185}$ The plaintiff appealed, but the appellate court affirmed, explaining that "the language employed in the Bates majority suggests that its holding

\footnotetext{
173. Rose I, 78 P.3d at 800 .

174. Id.

175. Id.

176. Id.

177. Id.

178. Rose v. Via Christi Health Sys., Inc. (Rose II), 113 P.3d 241, 243 (Kan. 2005).

179. The defendant hospital filed a cross-appeal in the event the appellate court reversed the trial court's grant of the motion to offset. Rose I, 78 P.3d at 802 . The write-off issue is the crux of the cross-appeal in Rose I.

180. See id. at 806 ("Because health care providers voluntarily contract with Medicare in the same manner as they contract with other private insurers for reduced rates, the benefit of the writeoffs should be attributed to the Medicare participant rather than the health care provider."). This distinction was based on a contractual, benefit-of-the-bargain, analysis: Medicare, unlike Medicaid, generally requires its beneficiaries to pay premiums. Id. at 803 .

181. Liberty v. Westwood United Super, Inc., No. 89,143, 2005 WL 1006363, at *5 (Kan. Ct. App. Apr. 29, 2005).

182. No. 90, 246, 2005 WL 400404, at *4 (Kan. Ct. App. Feb. 18, 2005).

183. $2005 \mathrm{WL} 1006363$, at $* 5$.

184. Fisher, 2005 WL 400404 , at *1.

185. Id.
} 
was not principally driven by the fact that the write-off was mandated by a Medicaid contract." "186 The same three-judge panel decided Liberty. In language almost verbatim to that in Fischer, ${ }^{187}$ the Liberty court extended Bates to Medicare write-offs. ${ }^{188}$

The Fischer and Liberty appellate court clearly expected the Kansas Supreme Court to answer the write-off question. ${ }^{189}$ However, the Kansas Supreme Court did little to meet these expectations. Instead of solving this question, the court left the write-off issue undecided by limiting Rose II to cases where the tortfeasor plays the roles of both the defendant and the medical service provider. ${ }^{190}$

In what one commentator has named a "disconnect between the Kansas Court of Appeals and the Kansas Supreme Court," 191 the preceding cases set the groundwork for uncertainty. Presently, a defendant may introduce evidence of write-offs. Per Bates, the "amount due" is the actual amount paid because the medical service provider cannot charge Medicaid patients for the write-off. ${ }^{192}$ Similarly, under Rose II, a defendant may introduce evidence of write-offs if the tortfeasor is both the defendant and the medical service provider. ${ }^{193}$ While Rose I purported to limit Bates to Medicaid cases, ${ }^{194}$ Rose II brings to question the precedential value of this distinction. ${ }^{195}$

186. Id. at *2. In Fischer, the Kansas Court of Appeals explained that, per Kansas Supreme Court Rule 7.06(a), "[t]he granting of the rehearing suspended the effect of the original decision until the matter is decided on rehearing." Id. at *5.

187. See Liberty, 2005 WL 1006363 , at $* 5$ (explaining that because Rose I was scheduled for rehearing, the court of appeals could apply Bates to Medicare write-offs).

188. Id. at *5-6. The court specifically noted:

$[\mathrm{T}]$ he issue presented is not the applicability of the collateral source rule, but rather "the reasonable value of medical care and expenses for the treatment of [the victim's] injuries." ... [T] "customary charge" for their medical treatment and, thus, represents the reasonable value of their damages attributable to medical expenses.

Id. (quoting Bates).

189. See id. at *6 ("Perhaps by the time this matter is retried, the district court will have the benefit of a final decision in the Rose case. If not, the district court's application of Bates would be legally and logically sound.").

190. Rose v. Via Christi Health Sys., Inc. (Rose II), 113 P.3d 241, 248 (Kan. 2005).

191. Young, supra note 3, at 152.

192. Bates v. Hogg, 921 P.2d 249, 253 (Kan. Ct. App. 1996), superseded by statute on other grounds, KAN. STAT. ANN. $\S \S 60-226(\mathrm{~b})$, (c), -237(c) (1999), as recognized in Frans v. Gausman, 6 P.3d 432, 440 (Kan. Ct. App. 2000).

193. See Rose II, 113 P.3d at 246 (condoning the trial court's decision to allow a credit against the plaintiff's damages award for the medical expenses written off by Medicare).

194. Rose v. Via Christi Health Sys., Inc. (Rose I), 78 P.3d 798, 802 (Kan. 2003).

195. Rose II, 113 P.3d at 248. 
Nevertheless, the Kansas Court of Appeals concluded in Fisher and Liberty that Bates applies to all write-offs. ${ }^{196}$ The court further noted that the actual amount paid constitutes the reasonable value. ${ }^{197}$ Taking these decisions at face value, their practical result is simple: if the collateral source rule is inapposite to all write-offs, and the reasonable value of the services comprises the actual amount paid to the medical service provider, then no plaintiff may recover more than the actual amount paid to the medical service provider. ${ }^{198}$

The history, approaches, and details of the collateral source rule in the Medicare and Medicaid contexts highlight the rule's complications. Making effective use of these tools, Kansas must mold a rule that will respect both the rule's policies and the Kansas Constitution.

\section{ANALYSIS}

Kansas courts have blatantly ignored the collateral source rule's policies. Absent a consideration of the policies underlying the collateral source rule, the application of any of the three approaches yields a legal rule improperly divorced from its roots. This is exactly the type of rule Kansas courts have sired - the rationale that courts should not hold defendants fully liable merely because neither the defendant nor his insurance company incurred the loss carelessly disrespects the rule's purpose.

Specifically challenging this payment rationale, this Part proposes three arguments. First, because policies of deterrence and accountability

196. Liberty v. Westwood United Super, Inc., No. 89,143, 2005 WL 1006363, at *5 (Kan. Ct. App. Apr. 29, 2005). The Fisher court explained it was not bound by Rose I because the Kansas Supreme Court had granted a motion for rehearing prior to oral arguments in Fisher:

Obviously, our Supreme Court's [Rose I] majority decision would mandate that we reverse and remand in this case. However, prior to the oral arguments in our case, the Supreme Court granted a motion for rehearing or modification and set oral arguments on that motion .... Thus, we are not currently bound by that decision . . . [W]e now choose to proceed, based upon the currently effective precedent of Bates and upon our firm belief that the collateral source rule has no place in the determination of the proper measure of damages to be applied to all plaintiffs' economic damages.

Fisher v. Farmers Ins. Co., No. 90, 246, 2005 WL 400404, at*5 (Kan. Ct. App. Feb. 18, 2005).

197. See Liberty, 2005 WL 1006363, at *5 (citing Bates, 921 P.2d at 253) ("In short, the issue presented is not the applicability of the collateral source rule, but rather 'the reasonable value of the medical care' ... . [T] he amount permitted to be charged to Medicare patients is the 'customary charge' for their medical treatment and, thus, represents the reasonable value of their damages attributable to medical expenses.").

198. See Fisher, 2005 WL 400404, at *2 ("The principle of restoration should be applicable to all plaintiffs, regardless of whether they be uninsured, covered by Medicaid, covered by Medicare, covered by an employer's group health policy, or covered by an individually purchased private insurance contract."). 
underlie the Kansas collateral source rule, the rule applies to write-offs regardless of whether anyone has paid them. ${ }^{199}$ Second, a corollary of the first argument, the rule's policies demand a reasonable-value approach that allows courts to award plaintiffs the original amount billed by their medical service providers. ${ }^{200}$ Third, responding to a commentator's constitutional challenges to Senate Bill 335, ${ }^{201}$ this Part concludes that the Kansas legislature possesses the constitutional authority to abrogate the collateral source rule. ${ }^{202}$ However, in order to show that the collateral source rule is not bullet-proof, this Part ultimately discusses suggestions to strengthen legislative attempts to abrogate the rule against constitutional challenges. ${ }^{203}$

\section{A. Deterrence and Punishment: A Top-Down Approach to the Kansas Collateral Source Rule}

\section{A Theoretical Framework}

Many note that the plaintiff has received an undeserved windfall at the defendant's expense if the court includes a write-off in the plaintiff's damages award. ${ }^{204}$ Why, in other words, should the tortfeasor pay the plaintiff damages that neither he nor anyone else incurred? ${ }^{205}$ After all, the collateral source rule states that "payments from a collateral source shall not diminish the damages otherwise recoverable from the wrongdoer."206 Two policy prongs generally compose the counterargument. First, courts should not relieve the defendant from liability merely because no one paid the benefit. Second, if either the

\footnotetext{
199. See infra Part III.A.

200. See infra Part III.B.

201. See supra notes $151-53$ and accompanying text (summarizing Young's constitutional arguments).

202. See infra Part III.C.

203. See infra Part III.D.

204. See, e.g., Wildermuth v. Staton, No. Civ. A. 01-2418-CM, 2002 WL 922137, at *5 (D. Kan. Apr. 29, 2002) (explaining that "as the Kansas Court of Appeals noted in Bates, allowing a plaintiff to recover the amount of charges written-off would result in a windfall to the plaintiff. . . . '[T]he basic principle of damages is to make a party whole by putting it back in the same position, not to grant a windfall."” (quoting Stephan v. Wolfenbarger \& McCully, P.A., 690 P.2d 380, 385 (Kan. 1984))).

205. See Strahley v. Mercy Health Ctr. of Manhattan, Inc., No. Civ. A. 99-2439-KHV, 2000 WL 1745291 , at *2 (D. Kan. Nov. 9, 2000) ("No one, including plaintiffs, is liable for the amount of the write-offs. Therefore, they do not represent actual losses.").

206. Rose v. Via Christi Health Sys., Inc. (Rose II), 113 P.3d 241, 246 (Kan. 2005) (emphasis added) (quoting Moorhead v. Crozer Chester Med. Ctr., 765 A.2d 786, 790 (Pa. 2001)).
} 
defendant or the plaintiff must receive a windfall, justice demands that the plaintiff - not the defendant - profit from the collateral source. ${ }^{207}$

A more sound and less hasty response would look to the rule's foundation, seeking to determine the purpose of the rule and applying that purpose to the facts at issue. One might then pose the question: Does the purpose of the collateral source rule suggest either the defendant's conduct or the defendant herself should be covered? If so, then the collateral source rule should apply, notwithstanding any technicalities in the manner of payment or the collateral source's language itself. If not, then the court should not apply the collateral source rule to the defendant or her conduct and should, instead, allow her to introduce evidence of the collateral source's benefit or payment to the plaintiff. Much like original intent constitutional analysis, this framework allows practitioners to see a rule from the "top," or the policy, and apply that policy "down," or to the facts. ${ }^{208}$

This framework requires academics and practitioners to determine the collateral source rule's rationales. Courts generally advance two justifications, the first based on deterrence and accountability, ${ }^{209}$ and the second based on a benefit-of-the-bargain theory. ${ }^{210}$ Additionally, some commentators suggest a hidden function of the rule - "to assist plaintiffs' attorneys in financing lawsuits, since deducting insurance proceeds or government benefits from damages would reduce the size of the contingency fees available." ${ }^{211}$

\section{Payment or No Payment?: The Collateral Source Rule's}

Applicability to Write-offs in Light of Deterrence and Accountability

Kansas courts hold that where no one pays for the benefits, the collateral source rule does not apply. In Bates v. Hogg, ${ }^{212}$ the Kansas Court of Appeals noted that where Medicaid is at issue, the plaintiff is

207. Schonberger v. Roberts, 456 N.W.2d 201, 204 (Iowa 1990).

208. The author would like to thank Professor Scott Optican from the University of Auckland Law School in New Zealand for the "top-down" terminology.

209. John C. Moorhouse et al., Law \& Economics and Tort Law: A Survey of Scholarly Opinion, 62 AlB. L. Rev. 667, 688 (1998).

210. Id.

211. Id. at $688 \mathrm{n} .121$ ("[T] he collateral, source rule 'is in fact retained . . on the basis of its value in financing personal injury litigation." (quoting DAN B. DOBBS, HANDBOOK ON THE LAW OF REMEDIES $\S 8.10$, at $584(1973))$ ).

212. 921 P.2d 249 (Kan. Ct. App. 1996), superseded by statute on other grounds, Kan. STAT. ANN. $\S \S 60-226$ (b), (e), -237(c) (1999), as recognized in Frans v. Gausman, 6 P.3d 432, 440 (Kan. Ct. App. 2000). 
not entitled to submit evidence of write-offs. ${ }^{213}$ Unfortunately, the court provided little analysis in reaching its decision. Instead, the court merely stated that " $[\mathrm{n}]$ othing in the reasoning underlying the collateral source rule supports [the plaintiff's] position on this issue." 214

Wildermuth $v$. Staton ${ }^{215}$ provides an example of this payment rationale. There, the Kansas District Court extended Bates to Medicare write-offs and justified its decision on the lack of payment. ${ }^{216}$ The court concluded that, because no one paid for the write-off, the collateral source rule did not entitle the plaintiff to receive Medicare write-offs. ${ }^{217}$ Taken to its logical extreme, Wildermuth would likely extend Bates to private insurance write-offs, ${ }^{218}$ thereby limiting a plaintiff's recovery to the actual amount paid to the medical service provider, regardless of the program at issue.

As a matter of policy, the payment distinction stands on thin ground. ${ }^{219}$ Where the two primary policies underlying the Kansas collateral source rule are deterrence and accountability, ${ }^{220}$ a third party's payments or lack thereof should not determine the defendant's liability.

213. Id. at 253 .

214. Id.

215. No. Civ. A. 01-2418-CM, 2002 WL 922137 (D. Kan. Apr. 29, 2002).

216. Id. at *5 (citing Wentling v. Med. Anesthesia Servs., P.A., 701 P.2d 939, 949 (Kan. 1985)) ("[T]he collateral source rule, by its express terms, simply does not apply to write-offs of expenses that are never paid. The collateral source rule only excludes 'evidence of benefits paid by a collateral source."').

217. $I d$. at *8.

218. A syllogism clarifies this point: the Wildermuth court's decision hinges on whether someone actually paid the write-off. Plaintiffs never pay write-offs, even when they are insured under private insurance; by definition, write-offs are written off. Thus, if payment is a precondition of an economic damages award, plaintiffs will never receive write-offs, regardless of the benefit program or insurance company.

219. Arguably, the Wildermuth court misinterpreted the language upon which it relied. In noting that the collateral source rule only excludes evidence "paid" by collateral sources, the Wildermuth court cited Wentling v. Medical Anesthesia Services, P.A., 701 P.2d 939 (Kan. 1985), a case where the Kansas Supreme Court declared the first legislative attempt to abrogate the collateral source rule unconstitutional. Id. at *5. In Wentling, the Kansas Supreme Court noted:

"The collateral source rule permits an injured party to recover full compensatory damages

from a tortfeasor irrespective of the payment of any element of those damages by a

source independent of the tortfeasor. The rule also precludes admission of evidence paid

by a collateral source rule, except where such evidence clearly carries probative value on an issue not inherently related to measurement of damages."

Wentling, 701 P.2d at 949 (emphasis added) (quoting 3 MinZer, NATES, KimBALl, AXELROD \& GOLDSTEIN, DAMAGES IN TORT ACTIONS § 17.00, at 17-5 (1984)).

Nevertheless, the Kansas District Court concluded that the plaintiff's receipt of the Medicare write-off depends on whether someone had actually paid the write-off. Wildermuth's adamant emphasis on the payment/nonpayment distinction directly contradicts the "irrespective of the payment" language of the Wentling court. Thus, Wildermuth's reliance on Wentling is misplaced.

220. See supra note 113. 
The payment distinction is arbitrary, particularly when viewed through a policy lens.

A policy look at the collateral source rule as applicable to gratuitous benefits clarifies this point. Assume the plaintiff in the above illustration $^{221}$ lacks insurance. Assume further that one of the plaintiff's relatives pays the plaintiff's medical bill. The collateral source rule demands the defendant pay the entire amount originally owed by the plaintiff to the medical service provider, notwithstanding the payment by the plaintiff's relative. However, if the plaintiff's relative obtains a discount from the medical service provider resulting from his own negotiation, the collateral source rule still demands the defendant pay the full amount. The policies of deterrence and accountability demand that the court not diminish the defendant's culpability by a third-party discount.

Indeed, Bates failed to consider the collateral source rule's policies. In Kansas, deterrence and accountability constitute the Kansas collateral source rule's two primary policies. ${ }^{222}$ Thus, courts apply the collateral source rule under the assumption that deterrence embodies an important economic value. For example, if an insurance policy entitles A to receive $\$ 10,000$ for an injury, and the defendant negligently injures $\mathrm{A}$, under the collateral source rule $A$ will receive $\$ 10,000$ from the insurance policy and $\$ 10,000$ from the defendant, provided A did not contractually subrogate his rights to the insurance company. ${ }^{223}$ A policy of tortfeasor accountability also strengthens the plaintiff's case. ${ }^{224}$ Whether the plaintiff's insurance company paid for the write-off is factually irrelevant to the defendant's culpability. The defendant's negligence or intent in causing the tort does not change merely because a plaintiff obtained insurance or health benefits. As with deterrence, the payment is inapposite to the defendant's culpability. ${ }^{225}$

221. See supra Part II.A.2 (illustrating the dynamic among the collateral source rule, subrogation, and Medicare and Medicaid write-offs).

222. See supra note 113

223. Judge Posner provides an economic analysis of this scenario:

To permit the defendant to set up [the plaintiff's] insurance policy as a bar to the action would result in underdeterrence. The economic cost of the accident, however defrayed, is $\$ 10,000$, and if the judgment against him is zero, his incentive to spend up to $\$ 10,000$ (discounted by the probability of occurrence) to prevent a similar accident in the future will be reduced.

POSNER, supra note 17, at 201.

224. See supra note 113 (noting that accountability constitutes one of the collateral source rule's primary policies).

225. The analysis differs if the collateral source rule's desired function is, as some commentators have suggested, the assistance of plaintiffs and their attorneys in financing lawsuits. See supra note 
This does not imply the payment is irrelevant for all purposes. To most versions of the collateral source rule, the payment possesses legal weight insofar as it allows the fact finder to determine whether the payor, or the source of the benefit, is independent of the defendant. The facts in $\operatorname{Rose}^{226}$ serve as an example. There, the hospital played the roles of both the defendant and the medical service provider. ${ }^{227}$ Focusing on this factual distinction, the Rose II court noted that the collateral source rule only applies where the defendant and the payor are independent of each other. $^{22}$

\section{B. An Analysis of the Three Approaches}

Through lenses of deterrence and accountability, a top-down analysis leads to a single conclusion: A distinction between paid and unpaid write-offs is irrelevant because their payment or nonpayment does not alter the applicability of the deterrence and accountability policies to the defendant's liability. However, the notion that the collateral source rule applies to write-offs in the absence of a legislative enactment ordering otherwise does not end the legal inquiry. The question of whether the collateral source rule necessarily precludes defendants from introducing evidence of write-offs remains unanswered.

This question is crucial. Because its answer may be "no," this issue will ultimately determine whether the plaintiff receives them. If the collateral source rule, by mere virtue of its applicability, prohibits introduction of evidence of write-offs, then the plaintiff ought to recover the original amount billed by his medical service provider. Some courts have held the opposite. Even if applicable, these courts hold that the rule does not impose on the court a duty to award to the plaintiff the original

211 and accompanying text (describing the financing-litigation policy). If the policy starting point is the financing of litigation, then one cannot as easily make the case that the payment distinction is inapposite. Here, the plaintiff's recovery of the actual amount paid arguably consummates the financing-litigation policy. After all, once the plaintiff recovers an additional monetary amount - the double damages award-but does not receive the write-off, the plaintiff can much more easily finance the litigation. Viewed under this policy, a court that allows the plaintiff to receive the writeoff may often award the plaintiff more than the cost of litigation, thereby exceeding the purported benefit of the financing-litigation policy. However, courts generally do not subscribe to this policy. Even assuming that a court follows this rationale, the plaintiff's recovery of the original amount billed by the medical service provider would more strongly achieve the policy's purpose of aiding plaintiffs and their attorneys in financing litigation.

226. See supra notes 169-81 and accompanying text (discussing the relevant facts of the Rose decisions).

227. See supra note 172 and accompanying text.

228. Rose v. Via Christi Health Sys., Inc. (Rose II), 113 P.3d 241, 245-46 (Kan. 2005) (quoting Thompson v. KFB Ins. Co., 850 P.2d 773, 776 (Kan. 1993)). 
amount billed by the medical service provider. ${ }^{229}$ In addressing this question, courts have used three general approaches. ${ }^{230}$ Of these, only the reasonable-value approach respects both the collateral source rule's underlying policies of accountability and deterrence and the Kansas Constitution.

1. Protect the Rich, and Forget the Poor: The Benefit-of-the-Bargain Approach's Shortcomings

Through the benefit-of-the-bargain approach, plaintiffs may recover the original amount billed by their medical service providers only if their healthcare benefits bear contractual consideration. ${ }^{231}$ If, on the other hand, the benefits do not bear consideration, plaintiffs ought to recover only the actual amount paid to the medical service providers.

This approach has encountered significant opposition within the courts. This Comment emphasizes two of the approach's most piercing critiques. First, the approach irrationally discriminates among plaintiffs. Second, the approach could not survive scrutiny under the Equal Protection Clause of the Kansas Constitution. ${ }^{232}$

Because the Medicare and Medicaid premium structures differ significantly, ${ }^{233}$ courts applying the benefit-of-the-bargain approach distinguish between the two programs. Courts generally agree that a plaintiff who receives Medicaid benefits has not bargained for those benefits and, thus, the collateral source rule does not entitle her to the write-off. ${ }^{234}$ The same relative consistency does not hold true in Medicare cases. ${ }^{235}$ Most jurisdictions conclude that a beneficiary who chooses Medicare has paid premiums and, therefore, the collateral source rule entitles such beneficiary to collect the unpaid amount. ${ }^{236}$ In contrast, a minority holds that, although Medicare beneficiaries pay premiums, the

229. See supra Part II.A.3 (discussing the approaches different jurisdictions have taken in resolving the collateral source issue).

230. See id. (discussing the benefit-of-the-bargain approach, the actual-amount-paid approach, and the reasonable-value approach to dealing with write-offs).

231. See supra Part II.A.3.a (discussing the benefit-of-the-bargain approach to write-offs).

232. Here, the benefit-of-the-bargain approach, not the collateral source's abrogation, would likely violate the Equal Protection Clause. This Comment discusses the equal protection implications for the collateral source rule and proposes a solution to anticipated constitutional problems infra in Part III.D.

233. See supra Part II.A.1.a (discussing Medicare and Medicaid's payment structures).

234. Id.

235. Id.

236. Id. 
collateral source rule does not entitle plaintiffs to recover Medicare write-offs because plaintiffs never actually bargained for their benefits. ${ }^{237}$

This approach complicates the write-off issue and unnecessarily creates ambiguities for parties to exploit. Even assuming that the collateral source rule generally entitles Medicare beneficiaries to receive the benefit of their bargain, a factual discussion reveals that, although courts adopting the benefit-of-the-bargain approach generally award Medicare beneficiaries the write-off, even Medicare beneficiaries seldom bargain for their benefit. The Medicare beneficiary does not necessarily pay a premium - in fact, Medicare beneficiaries may obtain their programs for free if they have little income or resources. ${ }^{238}$ In these cases, the state pays the beneficiary's premiums and might, in some cases, even pay the beneficiary's deductibles and other medical expenses. If the difference between a plaintiff who can recover the write-off and one who cannot is whether he has actually bargained for a benefit, then even some Medicare recipients may not be entitled to the write-off. ${ }^{239}$

An often criticized aspect of the benefit-of-the-bargain approach is its inherent discrimination among beneficiaries from different programs and insurance companies. Fischer clarifies this discrepancy. There, the court noted " $[\mathrm{t}] \mathrm{he}$ principle of restoration should be applicable to all plaintiffs, regardless of whether they be uninsured, covered by Medicaid, covered by Medicare, covered by an employer's group health policy, or covered by an individually purchased private insurance contract." 240 Hence the constitutional problem: In Kansas this distinction may actually violate equal protection. The rationale that arbitrary discrimination among the injured violates the Kansas Constitution invalidates the benefit-of-the-bargain approach. Applying Wentling, if the legislature, in modifying the collateral source rule, intends to both lower liability insurance costs and limit the size of personal injury verdicts, then the distinction between plaintiffs with Medicaid and those with Medicare or private insurance does not further the legislature's purpose. ${ }^{241}$ The practical discrimination makes the constitutional problem obvious:

237. Id.

238. See supra notes 46-49 (explaining Medicaid eligibility requirements).

239. Even in private insurance, an individual seldom bargains with the insurance company. The assumption that a plaintiff may actually bargain with the government or with a private insurance company is a fiction. Therefore, Kansas courts should not be captivated by the "fairness" and consistency mirage provided by the benefit-of-the-bargain approach.

240. Fischer v. Farmers Ins. Co., No. 90, 246, 2005 WL 400404, at *2 (Kan. Ct. App. Feb. 18, 2005).

241. Id. 
Medicaid beneficiaries, generally the poor and disabled, ${ }^{242}$ recover much less in economic damages than those with Medicare or private insurance. Under Wentling, Farley, and Thompson, courts cannot square such an inequitable and irrational framework with the Equal Protection Clause of the Kansas Constitution.

2. Undermining the Collateral Source Rule Itself: The Actual-AmountPaid Approach

In many courts, whether the plaintiff's insurance company has paid the write-off is critical. However, this distinction directly encroaches on the collateral source rule's policies of deterrence and accountability. ${ }^{243}$ To place the result in terms of the rule's policies, a court allowing the plaintiff to only receive the actual amount paid to the medical service provider deters the defendant less than it would have otherwise and permits her to incur less of a loss than she would have but for the plaintiff's insurance or government benefits. The Kansas collateral source rule's twin policies compel the opposite result. ${ }^{244}$

\section{Misplaced Criticisms: A Defense of the Reasonable-Value Approach}

In Koffman v. Leichtfuss, ${ }^{245}$ the Wisconsin Supreme Court adopted the reasonable-value approach to address write-offs. The court adopted this approach for three reasons. First, applying "long-standing principles of Wisconsin law," 246 the court held a plaintiff may recover the reasonable value of the services rendered by his medical service provider; ${ }^{247}$ the focus, the court noted, is "on the reasonable value, not the actual charge." 248 Second, the court noted that a plaintiff's damages

242. See supra notes 46-49 (posing Medicaid eligibility requirements).

243. Neither has the Kansas legislature weakened the rationales of the collateral source rule. At most, one may infer a desire to counter the perceived medical malpractice crisis from the legislature's previous modifications of the rule. One cannot with any certainty assume that the legislature seeks to weaken the policies of deterrence and accountability absent significant legislative history supporting its modifications of the rule or the abrogation of the collateral source rule.

244. See Part III.A.2 (making this point regarding the policies of deterrence and accountability in the write-off context).

245. 630 N.W.2d 201, 209 (Wis. 2001).

246. Id. at 208.

247. Id. at 209 (citing Ellsworth v. Schelbrock, 611 N.W.2d 764 (Wis. 2000); Thoreson v. Milwaukee \& Suburban Transp. Co., 201 N.W.2d 745 (Wis. 1972); McLaughlin v. Chi., Milwaukee, St. Paul \& Pac. Ry. Co., 143 N.W.2d 32 (Wis. 1966)).

248. Id. 
may not be reduced by third-party payments or benefits. ${ }^{249}$ Third, the court relied on the insurer's right to subrogation, noting that because the insurer has a right to subrogation, the plaintiff will not attain a double recovery. ${ }^{250}$

As long as policies of deterrence and accountability stand as the collateral source rule's pillars, Kansas should apply the reasonable-value approach and allow the plaintiff to receive the original amount billed by the medical service provider. Only in this situation does the burden fall where it should - on the defendant. Again, a look at the illustration in Part II.2 helps one understand this argument. The burden of the write-off must fall on someone. If the court allows the plaintiff to receive the $\$ 15,000$ write-off, the burden falls on the defendant. Conversely, if the court denies the plaintiff the opportunity to obtain the write-off, the court will presumably relieve the defendant from some liability. Thus, the plaintiff receives less than he would have had the collateral source rule mandated a write-off award. The court relieves the defendant from $\$ 15,000$ of liability - he ultimately pays $\$ 35,000$. The plaintiff earns nothing, and Medicare is, again, at a $\$ 0$ balance because it automatically subrogates the $\$ 35,000$ paid to the medical service provider. The defendant, at least theoretically, pockets the medical service provider's $\$ 15,000$ concession.

Even where courts have used the reasonable-value approach, they disagree as to what constitutes a "reasonable value." In defining "reasonable value," courts utilize three variations. First, the original amount billed by the medical service provider constitutes the reasonable value of the services. ${ }^{251}$ Second, the first variation's antithesis: the reasonable value of the services does not include the write-off. ${ }^{252}$ Third, both the amount billed by the medical service provider and the amount paid by the insurance company are relevant to a factual determination of the services' reasonable value. ${ }^{253}$

However, criticisms focusing on the approach's consequent inconsistency are misplaced. While courts have applied this approach differently, a majority of jurisdictions has held that plaintiffs are entitled to the reasonable value of the services and that the original amount billed

\footnotetext{
249. Id.

250. See id. at 212 (“"T] he insurer's subrogation rights prevent a double recovery on the part of the plaintiff.").

251. See supra note 92 and accompanying text.

252. See supra note 93 and accompanying text.

253. See supra note 94 and accompanying text.
} 
by the medical service provider constitutes this value. ${ }^{254}$ The ambiguous definition of "reasonable value" does not, in other words, cause these legal inconsistencies. Rather, their bases lie in the courts' misunderstanding of the deterrence doctrine, a misconception of-or perhaps a failure to consider - the legislature's role in the public policy process, and a disregard of the collateral source rule's policies. Inconsistency is not an issue if one assumes the collateral source rule entitles plaintiffs to receive write-offs absent a legislative abrogation or modification of the rule. Otherwise, courts unjustly relieve the defendant from liability and significantly undermine the collateral source's underlying policies of deterrence and accountability.

\section{The Kansas Constitution Does Not Preclude the Collateral Source Rule's Abrogation}

Thus far, this Comment has arrived at the following conclusion: Absent a legislative rejection of the collateral source rule's policies, deterrence and accountability demand a reasonable-value approach that allows courts to award plaintiffs the original amount billed by their medical service providers. This Subpart deals with an equally important question: Can the Kansas legislature constitutionally abrogate the rule? A recently published Note concludes that the Kansas legislature neither should, as a policy matter, nor can, as a constitutional matter, abrogate the rule. ${ }^{255}$ Rather than answering whether the Kansas legislature should abrogate the rule, ${ }^{256}$ this Comment explores whether the legislature can, pursuant to the Kansas Constitution, do so. Thus, this Subpart ultimately concludes that the legislature indeed possesses the constitutional power to abrogate the rule.

254. See Robinson v. Bates, 828 N.E.2d 657, 663-69 (Ohio Ct. App. 2005) (surveying the law of several jurisdictions and concluding that the majority allows plaintiffs to recover the original amount billed by the medical service provider), discretionary appeal accepted, 835 N.E.2d 381 (Ohio 2005).

255. Young, supra note 3, at 167, 174.

256. Others have commented on this point. See generally Eaton, supra note 2 (surveying three unsuccessful attempts by the Kansas legislature to modify the Kansas collateral source rule); Young, supra note 3 (discussing the collateral source rule, the Kansas legislature's attempts to abrogate the rule, and probable impacts of such an abolition). 
1. The Kansas Legislature Does Not Lack a Rational Basis to Abrogate the Collateral Source Rule

Proponents of tort reform propose "facts" of a medical malpractice crisis in support of the collateral source rule's abrogation. ${ }^{257}$ Three notions fuel the perception of a medical malpractice crisis: First, both the number of tort claims and the resulting jury verdicts have astronomically increased; second, frivolous suits outnumber legitimate ones; and, third, doctors leave states without tort reforms because they cannot afford liability premiums. ${ }^{258}$ According to one commentator, questionable evidence supports these claims. ${ }^{259}$ The commentator notes that because this legislative purpose is no longer rational, the rule's abrogation cannot withstand constitutional scrutiny. ${ }^{260}$ Yet such a criticism ignores other reasons to abrogate the rule; the argument's basic fallacy lies in its assumption that the inexistence of a medical malpractice crisis is the only rational basis to abrogate the rule.

This Comment does not question the commentator's conclusions regarding the inexistence of a medical malpractice crisis. What this Comment does question is her argument's disconnect between its evidence and conclusion. Though sufficient, the existence of a medical malpractice crisis is not a necessary rational basis in the abrogation's constitutional calculus. Assuming arguendo that the medical malpractice crisis is an unfounded perception, the legislative acknowledgement of a weakening of the collateral source rule's pillars of deterrence and accountability suffices as a rational basis for abrogation. ${ }^{261}$

\footnotetext{
257. Young, supra note 3, at 161.

258. Id.

259. Calling into question these arguments, one commentator recently noted:

The number of tort claims filed has actually decreased per capita over the last ten years. Additionally, the amounts awarded by juries have increased proportionally with increases in medical costs and general inflation. Proponents of tort reform have also failed to produce evidence of the purported "frivolous" lawsuits. ... [And] [t]hreats that doctors are being forced to leave states without tort reforms are also unfounded. Id. at $161-62$.

260. Id. at $167-68$.

261. This Comment develops this argument infra in Part III.D.
} 
2. The Collateral Source Rule's Abrogation Does Not Necessarily Infringe on a Plaintiff's Constitutional Right to a Remedy

The collateral source rule's abrogation does not necessarily infringe on a plaintiff's constitutional right to a remedy. While the Kansas Constitution states that "[a]ll persons, for injuries suffered in person, reputation or property, shall have remedy by due course of law," ${ }^{262}$ it does not guarantee a right to double recoveries. In Farley v. Engelken, ${ }^{263}$ the Kansas Supreme Court did not reach the issue of whether the challenged suit violated the right to a remedy. ${ }^{264}$ Nonetheless, a holding that the Kansas Constitution entitles plaintiffs to the write-offs necessarily implies that the Kansas Constitution's right to a remedy requires courts to award the plaintiffs the double recovery imposed by the common law collateral source rule. Notwithstanding the rule's longstanding and well-settled common law doctrine, the Constitution neither expressly nor implicitly guarantees a double recovery.

\section{The Collateral Source Rule's Abrogation Does Not Infringe on a Plaintiff's Equal Protection Guarantees}

Neither would the collateral source rule's abrogation necessarily violate the Kansas Constitution's Equal Protection Clause. ${ }^{265}$ Some have argued that allowing a jury to hear evidence of the plaintiff's insurance, but not evidence of the defendant's, "violates the Equal Protection Clause by treating litigants unequally." 266 The argument depends on the premise that admissibility of evidence of insurance would inevitably prejudice juries. ${ }^{267}$

However, one can easily see the logical fallacy in this straw man. The soundness of this equal protection argument depends on a single premise: If the Kansas legislature abrogates the collateral source rule, courts must allow juries to hear the evidence of collateral sources. This assumption is at best questionable. In fact, the Kansas legislature may couple its abrogation with a caveat — only the court, not the jury, may

\footnotetext{
262. KAN. CONST. Bill of Rights, $\S 18$.

263. 740 P.2d 1058 (Kan. 1987).

264. Id. at 1064 .

265. Contra Young, supra note 3, at 169 (stating the abolition of the collateral source rule will violate the Kansas Constitution's equal protection guarantee).

266. Id. (emphasis added).

267. Id.
} 
hear evidence of collateral sources. ${ }^{268}$ Effectively obviating jury prejudice, this approach would not violate the Equal Protection Clause of the Kansas Constitution.

\section{Can a Statute Abrogating the Kansas Collateral Source Rule Survive Constitutional Scrutiny?}

The abrogation of the collateral source rule, because of its societal impact, is bound to encounter ardent legislative and judicial opposition. At the legislative level, the opposition's weapons will be its members' written and spoken words. However, a court's weapon is much more unyielding: the Kansas Constitution. ${ }^{269}$ This Comment thus advises opponents of the collateral source rule to conduct an empirical study on the collateral source rule's impact on defendants. Otherwise, the collateral source rule could, as one commentator noted, face equal protection and rational basis challenges. ${ }^{270}$

Senate Bill 335's last version allowed the jury to consider the plaintiff's collateral benefits in its determination but required the jury to itemize the verdict and the court to calculate the plaintiff's damages minus his net collateral benefits. ${ }^{271}$ Had the bill passed, the Kansas Constitution would have likely invalidated this framework. ${ }^{272}$ Allowing the jury to hear evidence of the plaintiff's insurance, even if the court conducts the final calculation, does not necessarily prevent jury prejudice against the plaintiff. The jury could, for example, compensate for the insurance on the plaintiff's noneconomic damages. Instead, this Comment advises opponents of the collateral source rule to include a

268. See, e.g., MICH. COMP. LAWS ANN. § 600.6303(1) (West 2000) (allowing the admissibility of collateral source benefits "to the court in which the action was brought after a verdict for the plaintiff and before a judgment is entered on the verdict" (emphasis added)); MINN. STAT. ANN. § 548.36(5) (West 2000) (prohibiting courts from allowing juries to hear evidence of collateral sources).

269. Proponents of Senate Bill 335 have already considered some significant constitutional concerns. By applying the abrogation to "any action," legislators responded to the Wentling $v$. Medical Anesthesia Services, P.A., 701 P.2d 939 (Kan. 1985) decision, which partially invalidated KAN. STAT. ANN. $\S 60-471$, because it only applied to medical malpractice actions. See supra notes 124-32 and accompanying text (discussing Wentling). Similarly, proponents have eliminated the $\$ 150,000$ threshold. See supra note 129 and accompanying text (quoting Wentling on this point). In making this change, the legislature responded to Thompson v. KFB Insurance Co., 850 P.2d 773 (Kan. 1993). See supra text accompanying note 146 (noting Senate Bill 335 abrogates the collateral source rule in all cases, regardless of the plaintiff's damages).

270. Young, supra note 3, at 168-69.

271. See supra text accompanying notes 148-50.

272. See Young, supra note 3, at 169 (noting the abrogation of the collateral source rule would violate the Equal Protection Clause of the Kansas Constitution by allowing juries to consider-and thus be prejudiced by-evidence of the plaintiff's insurance). 
clause that effectively prohibits juries from hearing evidence of collateral source rules and, instead, allows courts to calculate the final damages award after the jury verdict. ${ }^{273}$

In light of the possible inexistence of a medical malpractice crisis, ${ }^{274}$ a legislature seeking to abrogate the rule must equip itself with a solid rational basis. A policy shift away from deterrence and accountability may satisfy such a test. The hypothesis that the collateral source rule does not deter defendants anymore because their liability insurance generally pays for the plaintiff's damages constitutes a starting point. However, this hypothesis does not prove that the establishment of liability insurance has diluted the rule's rationales. Thus, this Comment calls for empirical research on the deterrent value of the rule and for a legislative balancing of, on one hand, both the collateral source rule's deterrent and accountability policies and, on the other, the societal impact of the rule's abrogation. A legislative finding that the collateral source rule lacks deterrent value and a rejection of its accountability rationale will likely constitute a rational basis to adequately withstand constitutional scrutiny.

\section{CONCLUSION}

The Kansas collateral source rule has evoked at least four legislative battles. $^{275}$ In many states, the rule still stands, perhaps only as an archaic reminder that traditional deterrent and punitive policies may sometimes reign over what many consider common sense. In Kansas, this pattern is most evident in the context of Medicare and Medicaid, as the two programs have severely complicated the collateral source rule's application. $^{276}$

Pursuant to agreements between Medicare or Medicaid, on one hand, and the medical service provider, on the other, patients often receive discounted health care rates. Plaintiffs and defendants have taken hold of these write-offs and, whenever the issue arises, focus their debates on whether the plaintiff or the defendant ought to receive the windfall. These windfall sophisms — often adopted by courts - have convoluted the

273. See supra Part III.C.3 (noting this approach would likely withstand an equal protection challenge).

274. See Young, supra note 3, at 161-65 (arguing the nation is no longer experiencing a medical malpractice crisis).

275. See supra Part II.B.3 (discussing these constitutional challenges).

276. See supra notes $12-17$ and accompanying text (noting the difficulties facing the collateral source rule's application to write-offs). 
law and have too often unnecessarily prompted costly questions that should have never arisen.

The latest attempt of the Kansas legislature to abrogate the rule, Senate Bill 335, could have significantly altered the Kansas personal injury litigation landscape. ${ }^{277}$ However, until the Kansas legislature eliminates the collateral source rule, courts should respect its policies of deterrence and accountability. This does not imply, however, that the collateral source rule is constitutionally unyielding. Rather, the legislative process will determine whether the Kansas rule stays or goes; the Kansas Constitution does not prevent the rule's abrogation, particularly if the legislature couples its rule with a legislative balancing, specifically noting that the societal impact on plaintiffs outweighs the perceived deterrence and accountability values of the rule. ${ }^{278}$ Regardless, this decision befits a carefully reasoned legislative policy decision. Relevant considerations extend beyond the existence of a medical malpractice crisis or the rule's benefits to insurance companies. ${ }^{279}$ To reach a sound and rational policy, the Kansas legislature must, first, consider empirical research on the Kansas rule's deterrence and accountability effects and, second, weigh both policy values against the expected adverse effects of the Kansas collateral source rule's abrogation.

277. See supra Part II.B.4 (discussing Senate Bill 335).

278. See supra Part III.D (suggesting this as an attempt to avoid the possible constitutional problems associated with abrogation of the collateral source rule).

279. In her Note, Young states the Kansas legislature should not partially abrogate the collateral source rule because a medical malpractice crisis does not exist and insurance companies would unfairly benefit at the expense of plaintiffs, resulting in a "grave societal impact." See Young, supra note 3, at 161-67. This Comment partially rebuts these arguments, noting that the legislature has the constitutional power to entirely abrogate the rule. See supra Part III.C. 